\title{
Pro-Apoptotic Effects of JDA-202, a Novel Natural Diterpenoid, on Esophageal Cancer Through Targeting Peroxiredoxin I
}

\author{
Xiao-Jing Shi, ${ }^{*}$ Lina Ding, ${ }^{*}$ Wenjuan Zhou, ${ }^{*}$ Yage Ji, Junwei Wang, Huimin Wang, \\ Yongcheng Ma, Guozhong Jiang, Kai Tang, Yu Ke, Wen Zhao,' and Hong-Min Liu ${ }^{\dagger}$
}

\begin{abstract}
Aims: Esophageal cancer (EC) is an aggressive malignancy and the most common solid tumor of gastrointestinal tract all over the world, with high incidence in Asia. The current study was designed to investigate the anticancer efficacy and mechanism that is involved in the action of a natural ent-kaurene diterpenoid, JDA-202, targeting EC.

Results: We found that an antioxidant protein peroxiredoxin I (Prx I) was upregulated in human EC tissues as well as in EC cell lines. JDA-202, a novel natural compound isolated from Isodon rubescens (Labiatae), was proved to possess strong anti-proliferative activities on those cell lines. Importantly, JDA-202 does not only bind to Prx I directly and markedly inhibit the activity of Prx I in vitro, but it also significantly induces hydrogen peroxide $\left(\mathrm{H}_{2} \mathrm{O}_{2}\right)$-related cell death. Furthermore, overexpression of Prx I significantly reversed EC109 cell apoptosis caused by JDA-202, whereas short interfering RNA (siRNA)-induced Prx I knockdown resulted in marked cell death even without JDA-202 pretreatment. On the other hand, the increased phosphorylation of mitogen-activated protein kinase (MAPK) proteins (c-Jun N-terminal kinase [JNK], p38, and extracellular signal-regulated kinase [ERK]) by JDA-202 was suppressed by N-acetylcysteine (NAC) or catalase, a known reactive oxygen species (ROS) or $\mathrm{H}_{2} \mathrm{O}_{2}$ scavenger. JDA-202 also significantly inhibited the growth of EC109 tumor xenograft, without significant body weight loss and multi-organ toxicities.

Innovation and Conclusion: Our findings, for the first time, demonstrated that JDA-202 may serve as a lead compound, targeting the overexpressed Prx I in EC cell lines and ROS accumulation as well as inhibiting the activation of their downstream targets in MAPKs. Antioxid. Redox Signal. 27, 73-92.
\end{abstract}

Keywords: EC, $\mathrm{H}_{2} \mathrm{O}_{2}$, JDA-202, Prx I

\section{Introduction}

$\mathbf{E}$ SOPHAGEAL CANCER (EC) is one of the most common diagnosed aggressive malignant cancers and the sixth most common cause of cancer-related death worldwide $(20,40)$. Among EC patients, esophageal squamous carcinoma (ESC) is the predominant histological subtype in Asia, mainly in China and Japan (29). Surgery and chemo-radiotherapy are the major intervention for this remotely localized cancer; however, the overall 5-year survival rates are relatively low (57). Therefore, it remains a core mission to further explore the early pathogenesis and characteristics of EC and to develop novel effective targeting compounds without significant side effects.

As one of the most exciting milestones of ent-kaurene diterpenoid compounds, $L$-alanine-(14-oridonin) ester trifluoroacetate (HAO472) from Hengrui Medicine Co. Ltd. was recently advanced into phase I clinical trial (CTR20150246; www.chinadrugtrials.org.cn) by CFDA, to treat acute myelogenous leukemia. Previously, we had shown that one entkaurene diterpenoid compound Jaridonin could induce a series

Key Laboratory of Advanced Pharmaceutical Technology, Ministry of Education of China, Co-Innovation Center of Henan Province for New Drug R \& D and Preclinical Safety, School of Pharmaceutical Sciences, Zhengzhou University, Zhengzhou, China.

*These authors contributed equally to this work.

†These senior authors contributed equally to this work. 


\section{Innovation}

Esophageal cancer (EC) is an aggressive malignancy and the most common solid tumor of gastrointestinal tract all over the world, especially in Asia. In the current study, we identified that peroxiredoxin I (Prx I) was a potential druggable target in EC. The natural product JDA-202 not only induced EC cell apoptosis but also inhibited tumor growth by targeting the over-activated antioxidant protein Prx I, which was mainly associated with reactive oxygen species (ROS)-related activation in p38 mitogen-activated protein kinase (MAPK) signaling pathway, mitochondria injury, cell cycle arrest at G2/M phase, and apoptosis. These findings highlight that JDA-202 may serve as a promising candidate for EC treatment.

of EC cell apoptosis mediated by the mitochondria pathway (33) and $\mathrm{G}_{2} / \mathrm{M}$ phase cell cycle arrest, accompanied by activation of ATM-Chk1/2-Cdc25C pathway (34). Both pathways are associated with the elevated reactive oxygen species (ROS). Other ent-kaurene diterpenoid analogs, for example, Oridonin, the first ent-kaurane diterpenoid isolated from Isodon rubescens (Labiatae), could potently induce prostate cancer cell apoptosis via stimulating p53/p73 and PUMA expression (23). However, the direct targets of these ent-kaurene diterpenoid compounds on EC or other solid tumors remained not fully understood.

Peroxiredoxin I (Prx I) belongs to 2-Cys peroxiredoxins (Prx I- Prx IV), thiol-specific peroxidases that utilize cysteine as the primary site for oxidation and modulate several signaling pathways related to oxidation stress. Prx IV has been identified as a novel serum marker in ESC patients (11). Earlier reports revealed that Adenanthin with a common diterpenoid structure induced differentiation of leukemic cells and inhibited hepatocellular carcinoma (HCC) growth through targeting Prx I/II (18, 30, 31), indicating the involvement of Prx I/II in the development of these cancers. Elevated levels of Prx I were found in several types of cancers, including breast cancer $(7,55)$, human thyroid tumors (60), oral cancer (61), lung cancer (25), and others (54). Downregulation of Prx I expression or inhibition of Prx I activity by small-molecule inhibitors has been shown to effectively prevent progression of tumorigenesis $(5,8,12,15$, 37). Moreover, overexpression of Prx I can suppress ionizing radiation-induced cell apoptosis (27). Collectively, Prx I has been considered one of the important and promising anticancer targets and greatly attracted our attention, due to its function as a scavenger of intracellular hydrogen peroxide $\left(\mathrm{H}_{2} \mathrm{O}_{2}\right)$, the major form of ROS. However, the importance of oxidation-redoxidation-related oncogenesis is still debatable. Although inhibition of oxidative stress in the advanced stage of cancers may be beneficial (38), this strategy raises some additional side effects (3), including drug resistance and multi-targeted actions $(2,4)$. Therefore, it becomes necessary to further investigate the potential significance of Prx I, as an antioxidant protein, in EC development and to determine the characterization of Prx I as a druggable target, as well as to develop potent compounds specifically targeting this protein.

In this study, a stable in vitro screening method was set up to evaluate the peroxidase activity of Prx I or Prx II, which can be used to screen small-molecule inhibitors. We found that the level of Prx I expression was significantly increased in several EC cells and human cancers. JDA-202, a ent-kaurene diterpenoid compound isolated from I. rubescens (Labiatae), potently inhibited Prx I activity and exhibited good cytotoxic effects on the indicated cancer cell lines, compared with Oridonin, Jaridonin, and Adenanthin (Supplementary Table S1; Supplementary Data are available online at www.liebertpub. com/ars). Interestingly, our findings, for this first time, indicated that JDA-202 may serve as a lead compound, targeting the overexpressed Prx I in EC cell lines and ROS, especially $\mathrm{H}_{2} \mathrm{O}_{2}$, accumulation as well as inhibiting the activation of their downstream targets in mitogen-activated protein kinase (MAPK) and apoptotic pathways.

\section{Results}

\section{Preferential increases of Prx I expression in EC cell lines and human EC tissue sections}

First, the messenger RNA (mRNA) and protein expression profiles of Prxs and other well-known antioxidant proteins in three human EC cell lines (EC109, EC9706, and KYSE-450) and one normal human immortal esophageal cell line (HET1A) were analyzed by real-time polymerase chain reaction (PCR) and Western blot. Among them, the mRNA expression of Prx I was significantly increased to $3.3 \pm 0.1-, 3.7 \pm 0.1-$, and 1.8 \pm 0.2 -fold, respectively, in EC9706, EC109, and KYSE450 cells compared with that in HET-1A cells $(1.0 \pm 0.1$, Fig. 1A). The mRNA levels of the other Prx isoforms, including Prx II, III, IV, V, and VI, and the commonly recognized antioxidant proteins, including glutathione peroxidase (GPx), thioredoxin (Trx), catalase, and superoxide dismutase 1 (SOD1), did not show any significant alterations in those EC cell lines (Fig. 1A, B). Consistently, the protein levels of Prx I were also significantly enhanced to $2.9 \pm 0.1-, 3.2 \pm 0.1-$, and $2.5 \pm 0.3$-fold in EC9706, EC109, and KYSE-450 cells, respectively (Fig. 1C, D), compared with those levels in the HET-1A cells $(1.0 \pm 0.1)$. The increased protein levels of Prx I in those EC cells reported here were similar to the previous findings (13). However, we also found that the levels of the other Prx isoforms (Prx II-VI), Trx, catalase, and SOD1 did not exhibit any obvious differences in these EC cells, compared with those levels in HET-1A cells (Fig. 1C).

The EC tissue sections in Chinese Han patients were acquired and the expression level of Prx I in those sections was determined, using immunohistochemistry. Interestingly, we found that the expression of Prx I was also significantly increased to $195 \%(p<0.01)$ in the tumor area of these tissue sections $(n=16)$ than that in the adjacent normal tissue area $(100 \%, n=16$; Fig. 1E, F).

Consistent with the enhanced expression of Prx I in EC109, EC9706, and KYSE-450 cells, the proliferation rates were significantly higher than those of HET-1A ones, expressed by the absorbance at $490 \mathrm{~nm}$ versus days of cell growth (Fig. 1G). The efficiency of clone formation was also markedly enhanced to $2.8 \pm 0.1-, 3.0 \pm 0.2-$, and $2.3 \pm 0.1$-fold in those three EC cells, compared with that of HET-1A ones $(1.0 \pm 0.1$, Fig. $1 \mathrm{H}, \mathrm{I})$. Taken together, the expression level of Prx I was significantly higher in EC cells and human EC tissue. The increased proliferation rate and the enhanced expression of Prx I in those EC cells attracted us to perform the following experiments. 
A

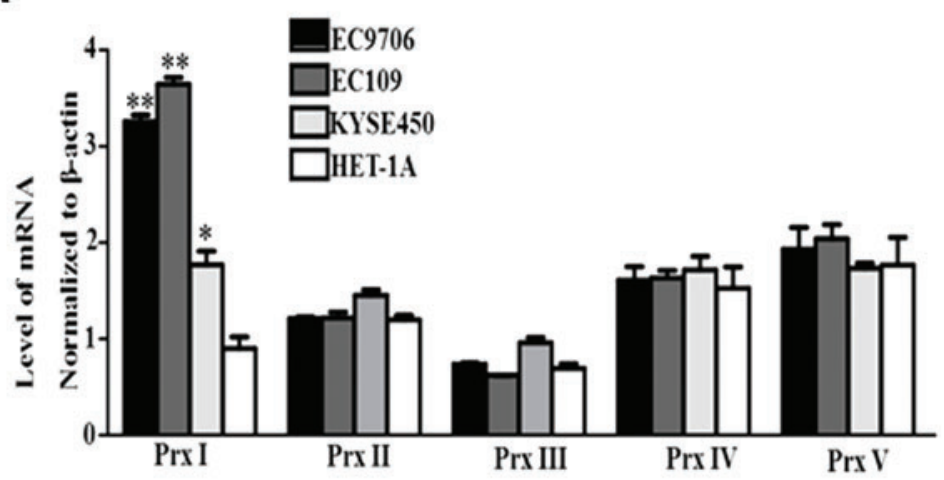

B

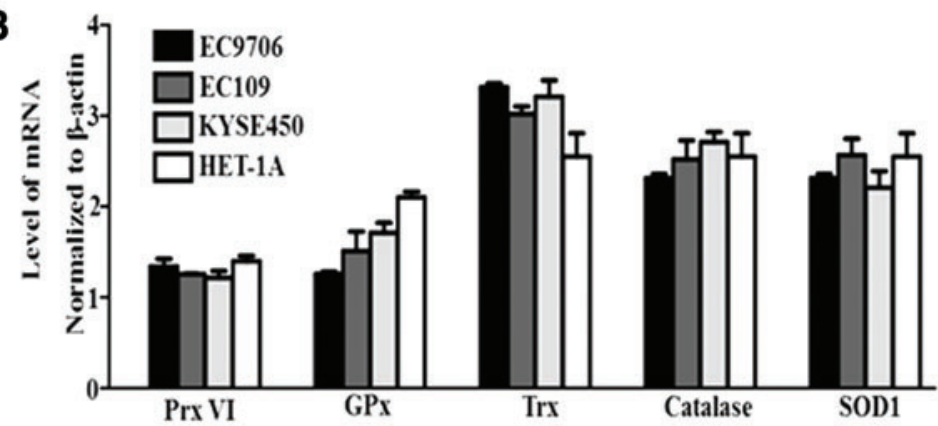

E
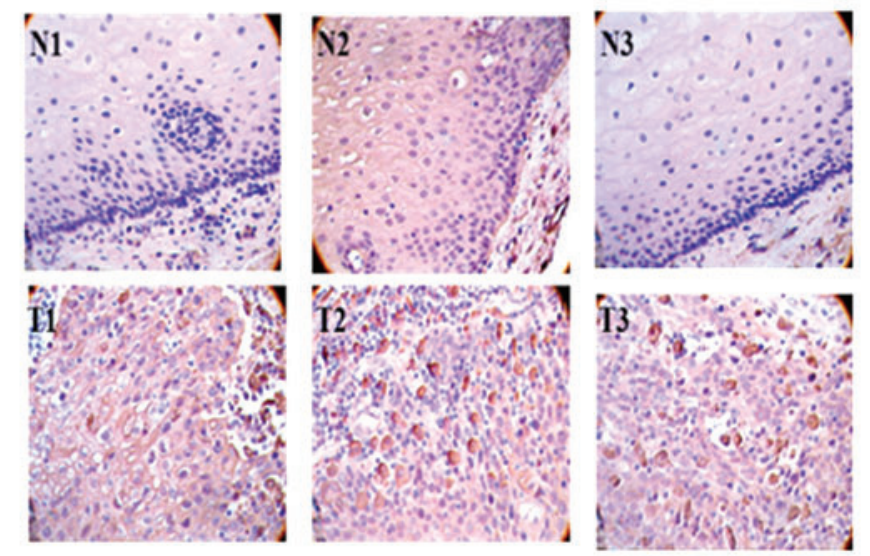

H

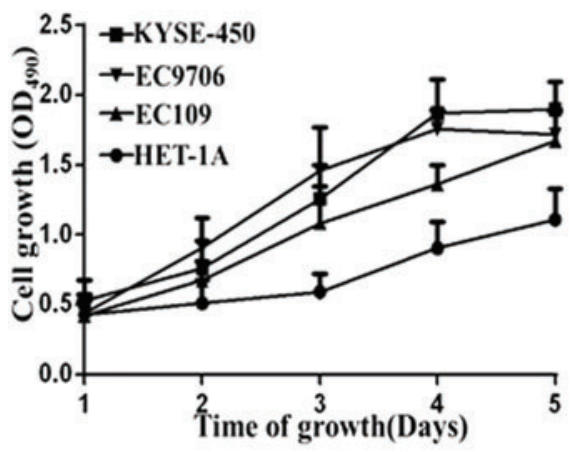

C

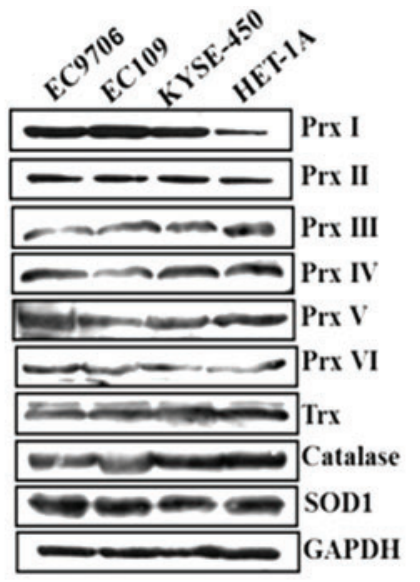

D

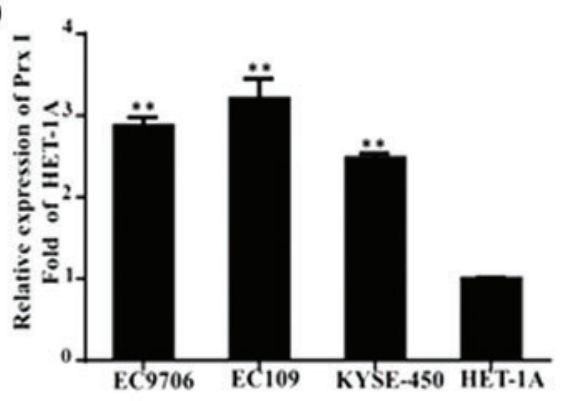

$\mathbf{F}$

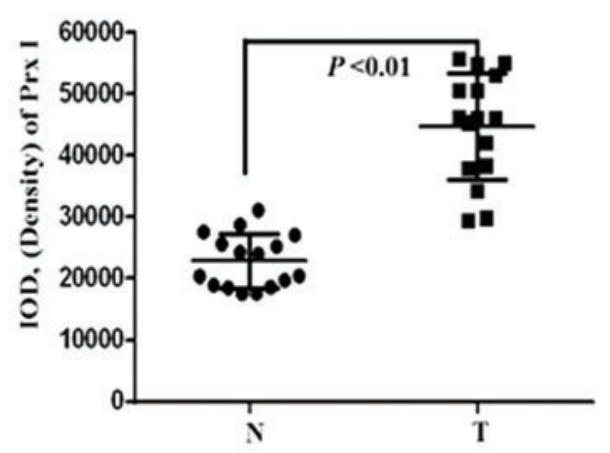

I

FIG. 1. Characteristic expression of Prx I in four different esophageal cells and in human esophageal normal and tumor tissues. The mRNA levels (A, B) of Prx I and the other antioxidant proteins, including: Prx II-Prx VI, GPx, Trx, catalase, and SOD1 in four different cultured esophageal cells (EC9706, EC109, KYSE-450, and HET-1A). The protein expression and levels (C, D) of Prxs (Prx I-Prx VI) and the other antioxidant proteins, including: Trx, catalase, and SOD1 in four different cultured esophageal cells. Three individual experiments were performed for each group. (E, F) The expression of Prx I in human normal esophageal and tumor tissue sections ( $n=16$ for each group). Curve of cell growth $(\mathbf{G})$ and clonogenicity $(\mathbf{H}, \mathbf{I})$ of the four cultured esophageal cells. Data are presented as means \pm SD. ${ }^{*} p<0.05$ or $* * p<0.01$, compared with the control group. GPx, glutathione peroxidase; mRNA, messenger RNA; Prx I, peroxiredoxin I; SD, standard deviation; SOD1, superoxide dismutase 1; Trx, thioredoxin. To see this illustration in color, the reader is referred to the web version of this article at www.liebertpub.com/ars 


\section{Targeting effects of JDA-202 to Prx I in vitro}

Considering the elevated levels of Prx I in EC cells, our following experiments were designed to screen candidate compounds, specifically targeting Prx I. The peroxidase activities of Prx I and Prx II in vitro were determined in the presence or absence of our title compound (JDA-202, Fig. 2A), Oridonin, Jaridonin, and Adenanthin (Supplementary Table S1). Interestingly, we found that JDA-202 was demonstrated to effectively and specifically inhibit the peroxidase activity of the recombinant Prx I, the same as that of Adenanthin (Supplementary Table S1 and Fig. 2B, C). However, the half-maximal inhibitory concentrations $\left(\mathrm{IC}_{50 \mathrm{~s}}\right)$ of JDA-202 on Prx I and Prx II activity were $5.3 \pm 0.7$ and $49.2 \pm 1.7 \mu M$, respectively, compared with those values of Adenanthin ( $4.9 \pm 0.7$ and $34.9 \pm 1.5 \mu M$, respectively), suggesting the better selectivity of JDA-202 on Prx I activity over Prx II (9.3-fold), compared with that of Adenanthin (7.1fold) (Supplementary Table S1). Therefore, JDA-202 was chosen for the following studies.

\section{Molecular modeling of JDA-202 to Prx I}

To determine whether there is a direct interaction between JDA-202 and Prx I, computer-based molecular modeling was performed. The crystal structure (PDB ID: 1QQ2) of dimeric Prx I was used and performed with the Surflex-Dock (SybylX2.1 program), based on the previous report (30). After the four rat-specific residues Ser14, Ile88, Ile144, and Ile156 were mutated to human-specific residues Asn14, Val88, Val144, and Thr156 and the Ser83 were mutated back to Cys, the Prx I protein was prepared with the module of Biopolymer. The geometry of the small molecule was optimized, using Tripos force field and Gasteiger-Huckel charge, with the convergence criteria $0.05 \mathrm{kcal} /(\mathrm{mol} \times \mathrm{A})$. Then, JDA-202 was manually docked into the pocket of the chain $\mathrm{A}$ of dimeric Prx I, using the module of Surflex-Dock and considering the lowest 10 conformers in energy (Fig. 2D). All the calculations were performed in Mac workstation. In the modeled JDA-202-Prx I complex, the following favorable interactions between JDA-202 and Prx I chain A were observed: a hydrogen bond between the $\mathrm{O}$ atom of the $\mathrm{C} 14 \mathrm{OH}$ group and the Phe50 main-chain NH group, another hydrogen bond between the $\mathrm{O}$ atom of the $\mathrm{C} 20 \mathrm{OCH}_{3}$ group and the $\mathrm{NH}_{2}$ group of Arg128, and nonpolar interactions between JDA-202 and Pro45, Leu46, Pro148, Thr49, Cys52, Val51, and Phe50 of Prx I. The binding site was located in the same binding pocket as that of Adenanthin (30), and the interaction models are quite similar to those of Adenanthin. These computer-based calculations and findings approved the direct interaction between JDA-202 and Prx I.

\section{Interaction between JDA-202 and Prx I}

To further confirm the direct interaction of JDA-202 and Prx I, the binding affinity was performed by isothermal titration calorimetry (ITC). JDA-202 was used as the titrant and Prx I was used as the titrand to generate an ideal fit for the thermogram. The results showed that JDA-202 interacted with Prx I with a dissociation constant $\left(\mathrm{K}_{\mathrm{d}}\right)$ of $\sim 2.0 \mu M$ (Fig. $\left.2 \mathrm{H}\right)$. Furthermore, site-specific mutations of the key residues of Prx I (Phe50 to Ala50 [F50A] and Arg128 to Ala128 [R128A]) were performed to test the specific interaction and to confirm the loss of JDA-202 inhibition against Prx I. Interestingly, both F50A and R128A mutants of Prx I did not show any catalytic activity toward $\mathrm{H}_{2} \mathrm{O}_{2}$ in our in vitro enzyme assay system, compared with the original Prx I (Prx I wt, Fig. 2E). The binding affinity of JDA-202 to the two Prx I mutants was also performed by ITC. Prx I R128A mutation did not show any interaction with JDA-202, whereas Prx I F50A mutation still exhibited potent binding affinity with JDA-202 (dissociation constant of $\sim 5.0 \mu M$; Fig. 2I, J). Furthermore, computerbased molecular modeling was also performed (Fig. 2F, G). In the modeled JDA-202-Prx I F50A complex, JDA-202 interacted with Prx I F50A by four hydrogen bonds: two hydrogen bonds between the same $\mathrm{O}$ atom of the $\mathrm{C} 15$ with the Ala50 (1.9 $\AA$ ) or Val51 (2.1 $\AA$ ), another two hydrogen bonds between the Arg 128 two main-chain $\mathrm{NH}$ groups with the same $\mathrm{O}$ atom between the C20 (2.0 $\AA$ ) and C7 (2.3 $\AA$ ) group. In the modeled JDA-202-Prx I R128A complex, only two hydrogen bonds remained: between the same $\mathrm{O}$ atom of the $\mathrm{C} 14 \mathrm{OH}$ group with Phe50 (2.0 §) and Val51 (1.6 ̊). These findings suggested that both Phe50 and Arg128 residues are crucial for Prx I activity, and the inhibitory effect of JDA-202 to Prx I is associated with the specific binding of JDA-202 on Prx I sites at Phe50 and Arg128.

\section{Cytotoxicity of JDA-202 on cultured EC cells}

In the following experiments, the cytotoxicity of JDA-202 on EC109, EC9706, KYSE-450, and HET-1A cells was determined. Our results (Fig. 3A) showed that all three EC cell

FIG. 2. JDA-202 directly interacts with Prx I and inhibits its catalytic activity in vitro. (A) Chemical structure of JDA-202. (B) The recombinant Prx I protein was incubated with the indicated concentrations of JDA-202 for 0, 120, 240, 360, 480, and $600 \mathrm{~s}$ and their peroxidase activities were monitored. (C) The recombinant Prx I protein was incubated with the indicated concentrations of JDA-202 or adenanthin for $10 \mathrm{~min}$, and their peroxidase activities were monitored. (D) Binding model of JDA-202 in Prx I dimerization pocket. Dotted lines represent hydrogen bonds between JDA-202 and Prx I. Right figure is the $180^{\circ}$ northeast turn of the left figure. (E) The catalytic activities of Prx I and the two mutants (Prx I F50A and Prx I R128A) to $\mathrm{H}_{2} \mathrm{O}_{2}$. Data are presented as means \pm SD. Three individual experiments were performed for each group. (F, G) Binding models of JDA-202 in Prx I F50A or Prx I R128A dimerization pocket. (H-J) Binding affinity of Prx I, Prx I F50A, or Prx I R128A with JDA-202. Upper graph shows raw data from one titration of JDA-202 (2 mM) into a solution containing protein $(60 \mu M)$. The lower graph shows the integrated heats from the titrations of JDA-202 into a solution containing Prx I, Prx I F50A, or Prx I R128A as a function of their molar ratio. The solid lines represent the best-fit binding isotherms to the data (one set of sites model within the Origin software), (Prx I, $K=5.1 \pm 2.5 \times 10^{5} \mathrm{M}^{-1}, \Delta \mathrm{H}=$ $-386.5 \pm 11.7 \mathrm{cal} / \mathrm{mol}, \Delta \mathrm{S}=24.8 \mathrm{cal} / \mathrm{mol} / \mathrm{deg}$ and $n=3.9 \pm 0.1)$, and (Prx I F50A, $K=2.4 \pm 0.8 \times 10^{5} \quad \mathrm{M}^{-1}, \Delta \mathrm{H}^{2}=$ $-197.6 \pm 9.2 \mathrm{cal} / \mathrm{mol}, \Delta \mathrm{S}=23.9 \mathrm{cal} / \mathrm{mol} / \mathrm{deg}$ and $n=1.82 \pm 0.06) . \mathrm{H}_{2} \mathrm{O}_{2}$, hydrogen peroxide. To see this illustration in color, the reader is referred to the web version of this article at www.liebertpub.com/ars 
A

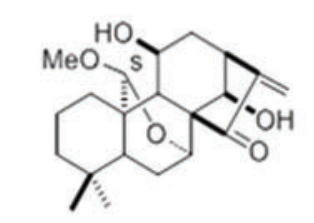

Chemical Formula: $\mathrm{C}_{21} \mathrm{H}_{30} \mathrm{O}_{5}$ Molecular Weight: 362.46

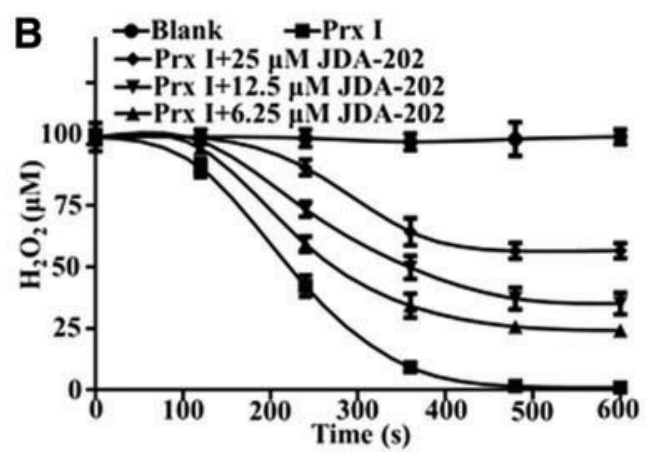

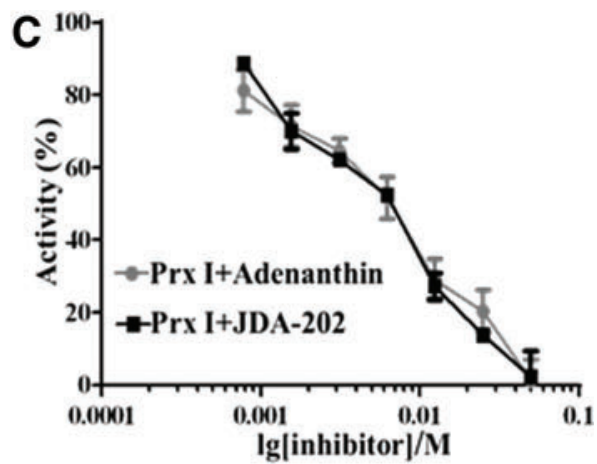

E
D

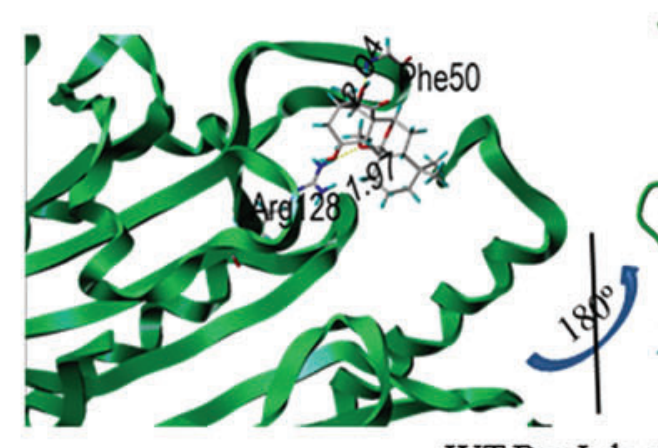

WT Prx I docking

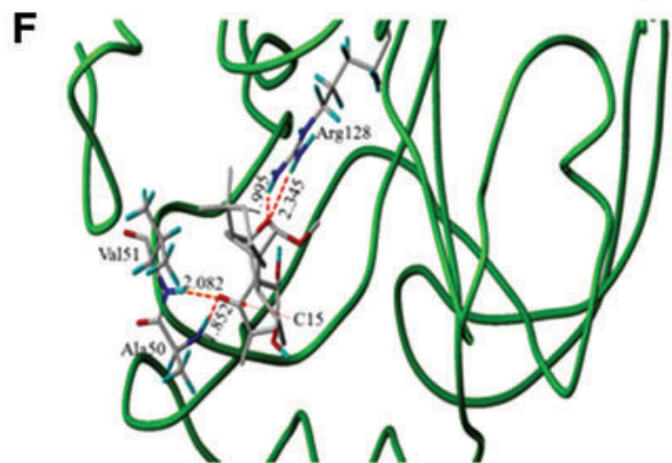

F50A mutation
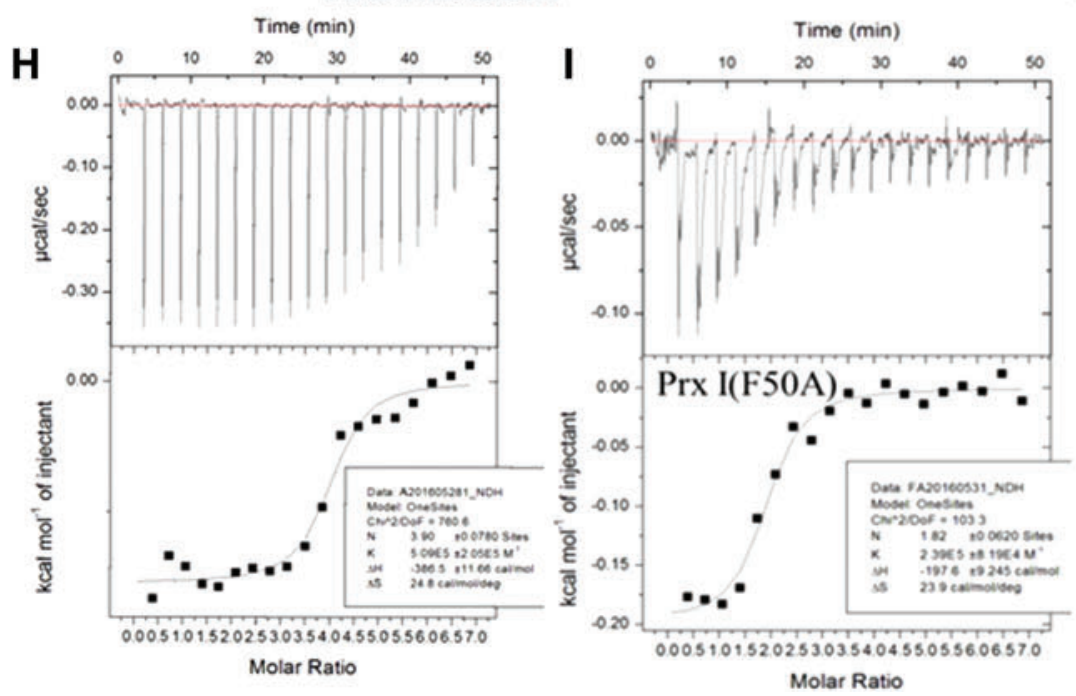

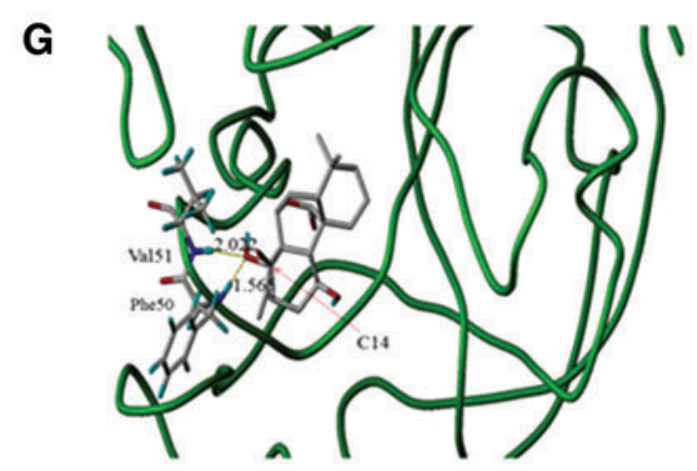

R128A mutation
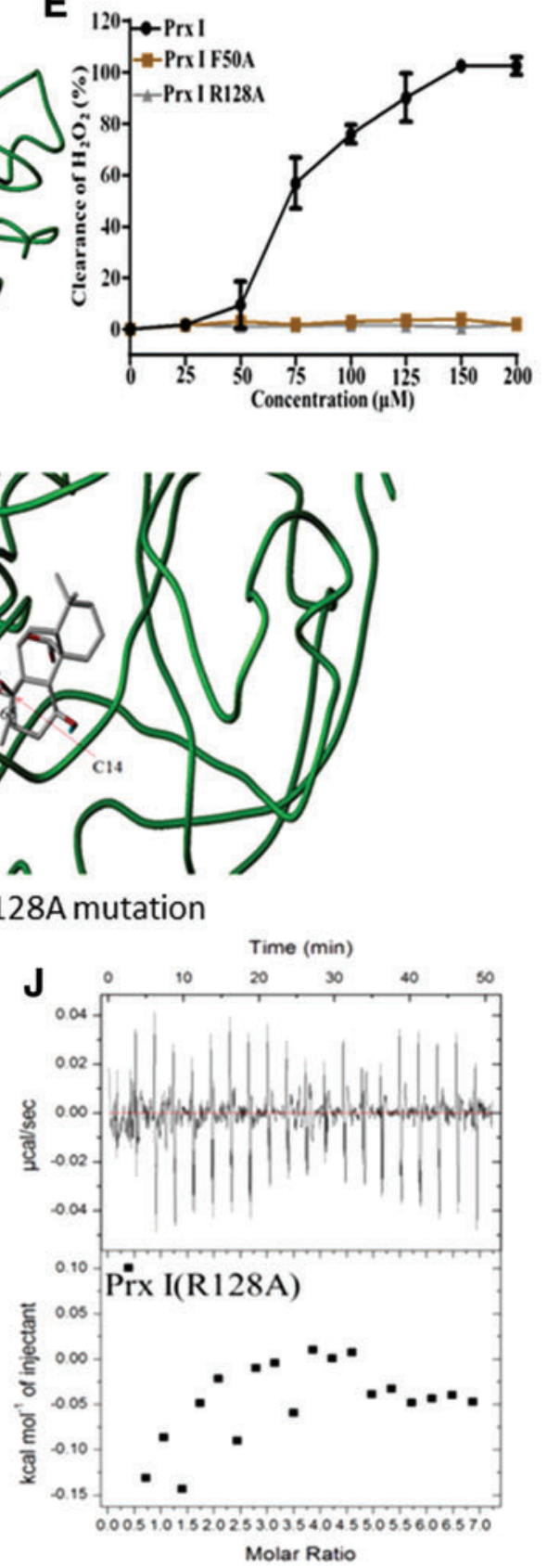
lines, especially EC109 and EC9706 cells, were more sensitive to JDA-202-induced growth inhibition $\left(\mathrm{IC}_{50 \text { s }}\right.$ were $8.6 \pm 0.7$ and $9.4 \pm 1.2 \mu M$, respectively), compared with HET-1A and KYSE-450 cells ( $\mathrm{IC}_{50 \mathrm{~S}}$ were $36.1 \pm 2.8$ and $26.2 \pm 4.1 \mu \mathrm{M}$, respectively). Furthermore, the cytotoxicity of JDA-202 on EC109 cells was stronger (2- and 1.7-fold, respectively) than that of Adenanthin after 48 and $72 \mathrm{~h}$ treatment $\left(\mathrm{IC}_{50}=16.0 \pm\right.$ 1.2 and $6.5 \pm 0.6 \mu M$, respectively; Supplementary Table S1).

On the other hand, EC109 (Fig. 3B, C) and KYSE-450 (Fig. 3D, E) cells treated with different concentrations of JDA-202 for $24 \mathrm{~h}$ significantly exhibited apoptosis-related morphological changes, such as cell shrinkage and rounding up, cell membrane blebbing, nuclear fragmentation, and condensation. Flow cytometric analysis showed that JDA202 markedly induced EC109 (Fig. 3F-I) and KYSE-450 (Fig. 3J-M) cell apoptosis in a concentration- or timedependent manner. Specifically, after 24 and $48 \mathrm{~h}$ treatment with $40 \mu M$ JDA-202, the percentages of apoptotic cells were $57.3 \% \pm 2.5 \%$ and $74.7 \% \pm 0.4 \%$, respectively, compared with those of the control group $(6.2 \% \pm 0.7 \%$ and $2.1 \% \pm 0.15 \%$ ) in EC109 cells (Fig. 3H, I). Similarly, the percentage of apoptotic cells after JDA-202 treatment was $33.9 \% \pm 1.8 \%$ and $35.8 \% \pm 0.4 \%$, respectively, comparable to those of the control group $(6.6 \% \pm 0.7 \%$ and $4.1 \% \pm 0.7 \%)$ in KYSE-450 cells (Fig. 3L, M).

Furthermore, we found that the level of Bcl-2 was downregulated and the level of Bax was upregulated by JDA-202 treatment in both EC109 (Fig. 3N-P) and KYSE-450 (Fig. 3Q-S) cells. JDA-202 treatment also resulted in the increased levels of the active forms of caspases 9, 7, 3, and PARP (Fig. 3N-S). Pretreatment with a caspase-3-specific inhibitor (Ac-DEVD-CHO, Fig. 3T) and a pan-caspase inhibitor (Z-VAD-FMK, Fig. 3U) significantly attenuated the pro-apoptotic effect of JDA-202 toward EC109 cells.

Cell cycle analysis was also performed in EC109 (Fig. 4A-D) and KYSE-450 (Fig. 4E-H) cells after treatment with 10, 20, and $40 \mu \mathrm{M}$ of JDA-202 for 12 or $24 \mathrm{~h}$. The percentage of cells in the $\mathrm{G}_{2} / \mathrm{M}$ phase for $12 \mathrm{~h}$ was increased to $1.4-, 2.2-$, and $2.7-$ fold, respectively, compared with the controls (Fig. 4C); whereas these values for $24 \mathrm{~h}$ were 1.4-, 2.0-, and 2.7-fold, respectively. Similarly, JDA-202 treatment also resulted in $\mathrm{G}_{2} / \mathrm{M}$ phase arrest in KYSE-450 cells in a concentration- or time-dependent manner (Fig. 4E-H). Canonically, alteration of $\mathrm{G}_{2} / \mathrm{M}$ checkpoint proteins expression, such as $\mathrm{p} 53, \mathrm{Cdc} 2$, and $\mathrm{Cdk} 2$, is related with $\mathrm{G}_{2} / \mathrm{M}$ arrest. Accordingly, we investigated whether JDA-202 could affect the expression of these proteins. Our results showed that JDA-202 significantly in- creased the levels of p53 and phosphorylation of p53 at Ser $^{15}$, $\mathrm{Cdc} 2$ at $\mathrm{Tyr}^{15}$, and $\mathrm{Cdk} 2$ at $\mathrm{Thr}^{160}$ in a concentrationdependent manner in both EC109 (Fig. 4I, J) and KYSE-450 cells (Fig. 4K, L). However, treatment with JDA-202 did not induce any changes in total $\mathrm{Cdc} 2$ and Cdk2 levels. These results indicated that the $\mathrm{G}_{2} / \mathrm{M}$ checkpoint proteins may be involved in the JDA-202-induced cell cycle arrest.

\section{JDA-202-induced EC cell apoptosis is associated with intracellular ROS accumulation}

It is known that an excessive amount of ROS accumulation and persistent oxidative stress may render some cancer cells susceptible to ROS-enhancing agents $(50,58)$; for example, some natural products (33). The increased levels of Prx I in the EC cells made us further address whether the levels of ROS, especially $\mathrm{H}_{2} \mathrm{O}_{2}$, mainly eliminated by Prx I, could contribute to the response of EC cells to JDA-202. Therefore, the four cell lines indicated earlier were treated with 10 and $20 \mu M$ JDA-202 for $24 \mathrm{~h}$, and the intracellular levels of ROS and $\mathrm{H}_{2} \mathrm{O}_{2}$ were then determined. We found that JDA-202 treatment resulted in a marked increase of ROS (Fig. 5A and Supplementary Fig. S4) and $\mathrm{H}_{2} \mathrm{O}_{2}$ levels (Fig. 5B) in EC109 and EC9706 cells, without significant effects on HET-1A cells. However, the level of superoxide anion in EC109 cells treated by JDA-202 was not altered, compared with that in the untreated cells (Supplementary Fig. S5).

Importantly, in the EC109 cells that were pre-treated with $\mathrm{N}$-acetylcysteine (NAC), a non-enzymatic $\mathrm{H}_{2} \mathrm{O}_{2}$ scavenger, the JDA-202-related ROS accumulation was attenuated (Fig. 5C-E). Similar results were also obtained in the cells pretreated with 1 and $2 \mathrm{U} / \mathrm{L}$ catalase, an enzyme specifically removing $\mathrm{H}_{2} \mathrm{O}_{2}$ (54) (Fig. 5F-H). Furthermore, pretreatment with NAC or catalase in EC109 cells almost completely abrogated JDA-202-induced cytotoxicity (Fig. 5I) and loss of mitochondrial membrane potential $(\Delta \Psi m$, Fig. 5J-L). NAC pre-incubation in EC109 cells also reversed the expression levels of the upregulated Bax and the downregulated Bcl-2 by JDA-202 (Fig. 5M, N). These results indicated that the elevated $\mathrm{H}_{2} \mathrm{O}_{2}$ induced by JDA-202 is a dominant form of ROS in EC109 cells, which may be related to the targeted effects of JDA-202 on Prx I in these cancer cells.

\section{Prx I expression levels are closely associated with EC cell survival and the pro-apoptotic effects of JDA-202}

To determine the relationship between Prx I expression level and EC cell growth, EC109 cells were treated with

FIG. 3. Cytotoxicity of JDA-202 on cultured esophageal cancer cells. (A) Human esophageal cells were treated with different concentrations of JDA-202 for $24 \mathrm{~h}$. Cell viability was determined by MTT assay. Cells were cultured with different concentrations of JDA-202 $(0,10,20$, and $40 \mu M)$ for $24 \mathrm{~h}$; apoptosis-related morphology and nuclear condensation in EC109 (B, C) and KYSE-450 (D, E) cells were pictured by light and fluorescence microscopes. Cells were treated by JDA-202 for 24 or $48 \mathrm{~h}$; apoptosis cells were detected by using the Annexin V-FITC/PI double staining and analyzed by flow cytometry in EC109 (F, G) and KYSE-450 (J, K) cells. (H, I, L, M) are the quantitation of those apoptotic cells. EC109 (N-P) and KYSE$450(\mathbf{Q}-\mathbf{S})$ cells were treated with JDA-202 $(10,20$, and $40 \mu M)$ for $24 \mathrm{~h}$; the expression levels and quantitation of Bax, Bcl-2, caspases 9, 7, 3, and PARP were detected by Western blot, and Image J. EC109 cells were plated in 96-well plates. Twentyfour hours later, cells were pretreated with caspase-3 inhibitor (Ac-DEVD-CHO, T) or pan-caspase inhibitor (Z-VAD-FMK, U) for $1 \mathrm{~h}$ followed by 20 or $40 \mu M$ JDA-202 for an additional $24 \mathrm{~h}$. Viability of cells was measured by MTT assay. Data are presented as means \pm SD. Three individual experiments were performed for each group. $* p<0.05, * * p<0.01$ as compared with the controls. ${ }^{\# \#} p<0.01$ when the JDA-202 plus AC-DEVD-CHO or Z-VAD-FMK group is compared with the JDA-202 group. MTT, 3-(4, 5-dimethylthiazol-2-yl)-2, 5-diphenyltetrazolium bromide; PI, propidium iodide. To see this illustration in color, the reader is referred to the web version of this article at www.liebertpub.com/ars 

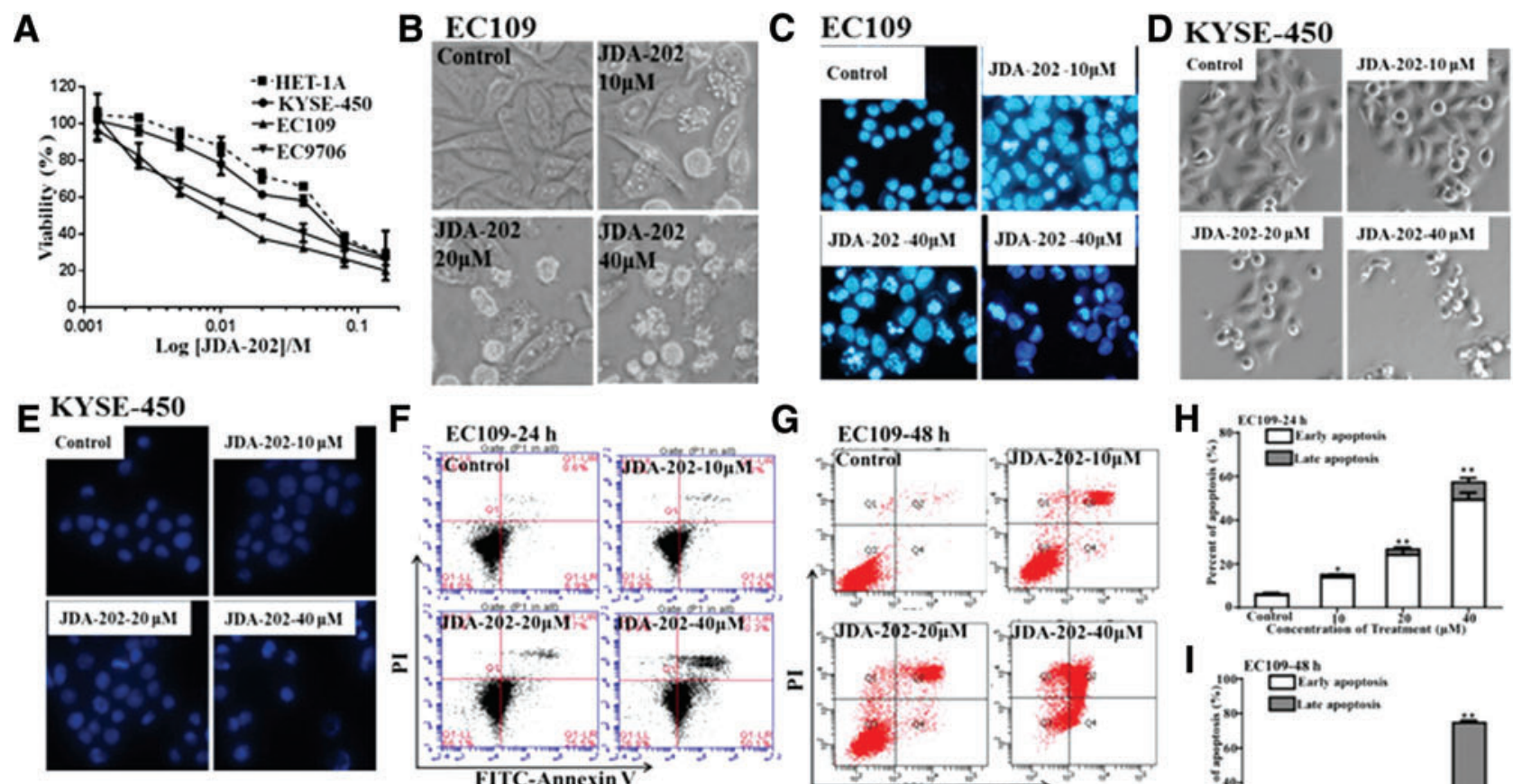

G

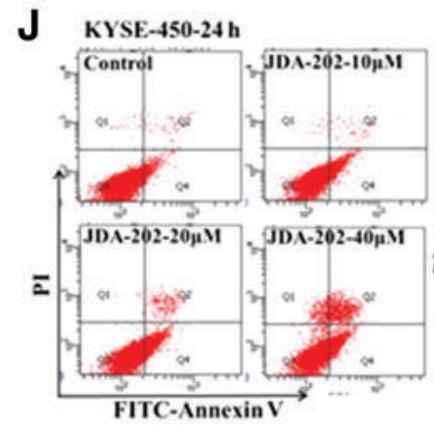

K KYSE-450-48h

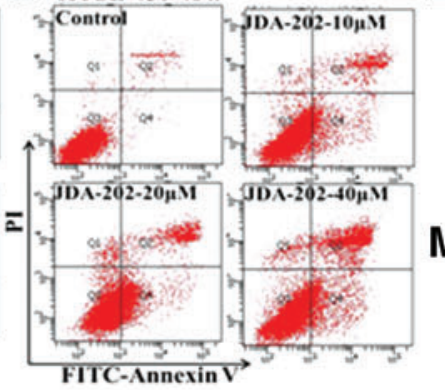

$L$

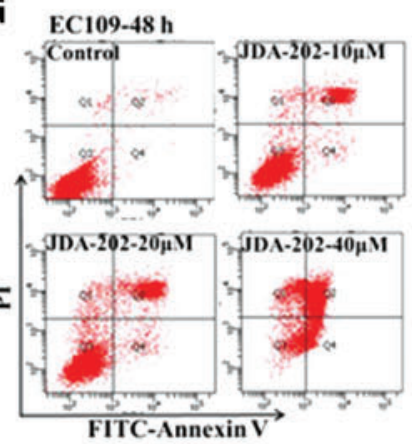

$\mathbf{H}$

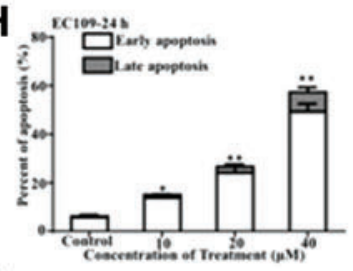

I
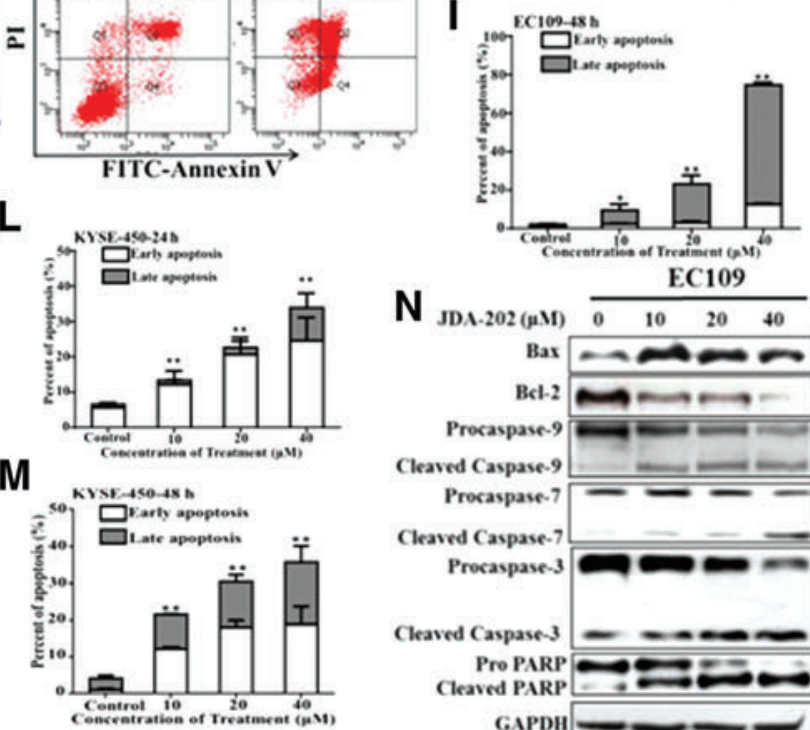

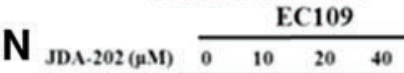

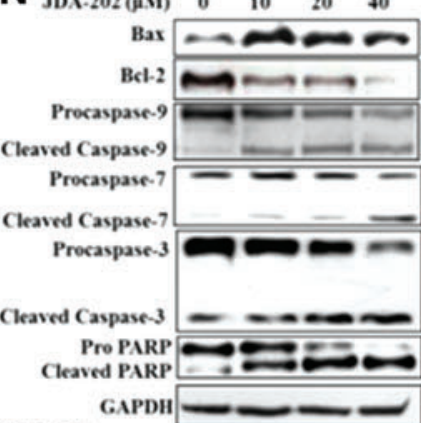

EC109

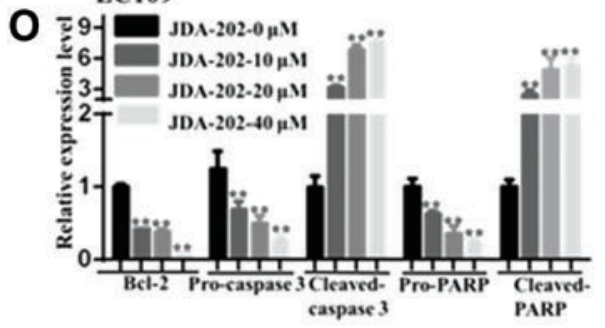

P $\quad$ EC109

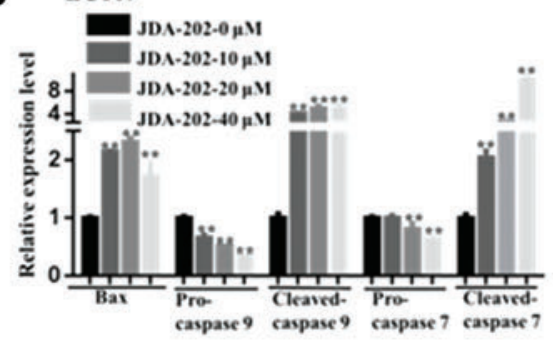

Q

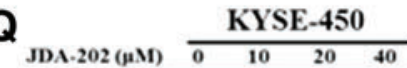

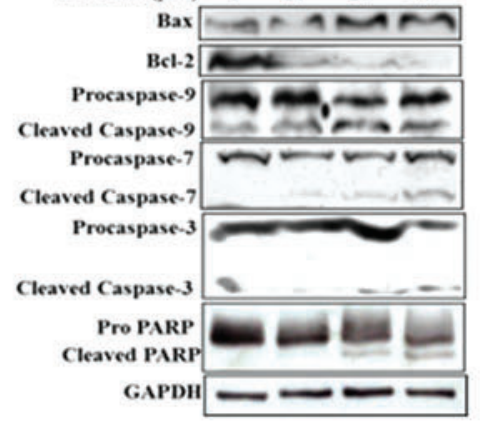

$\mathbf{T}$

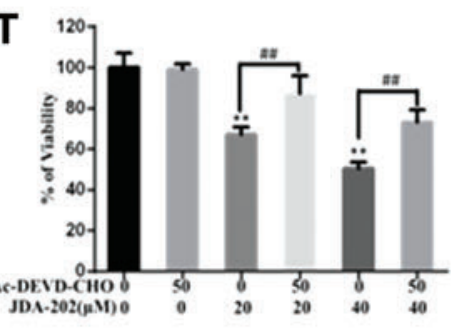

KYSE-450

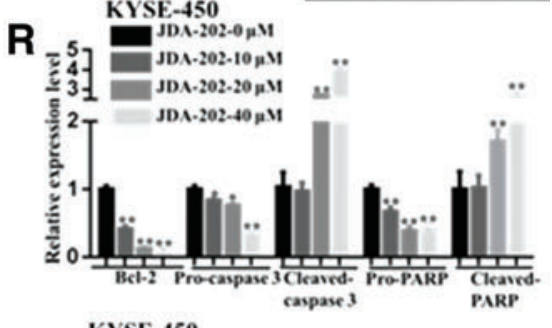

KYSE-450

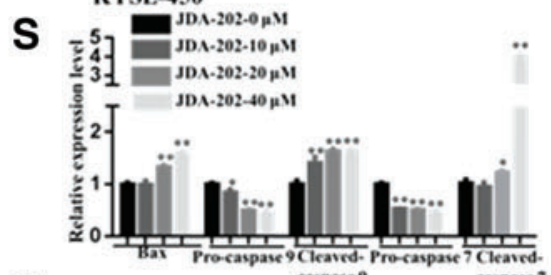

$\mathbf{U}$

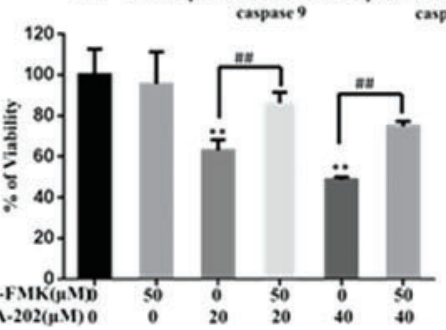


A

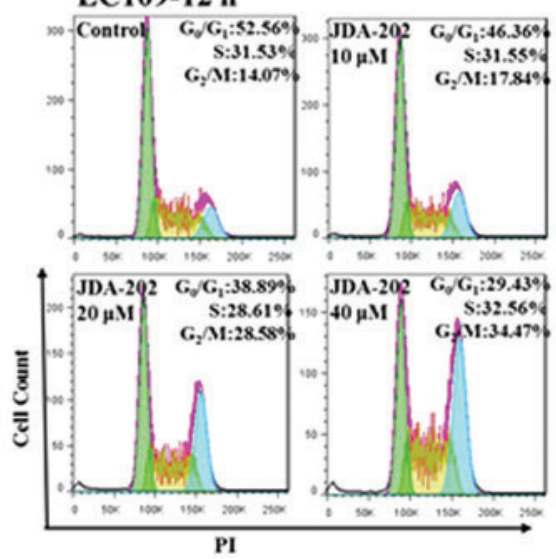

E

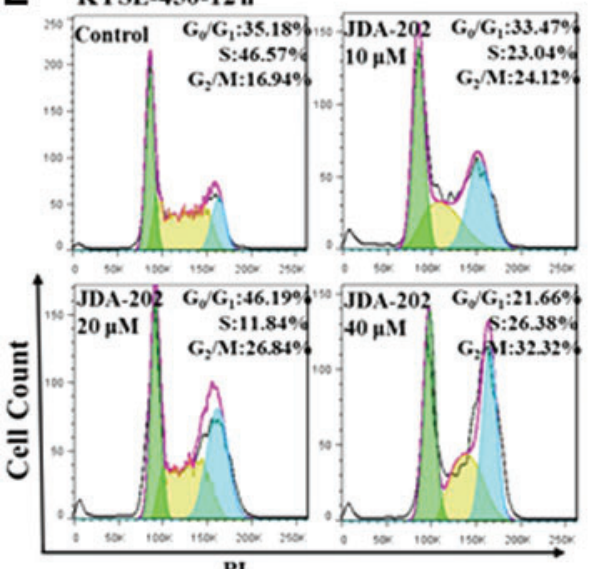

B

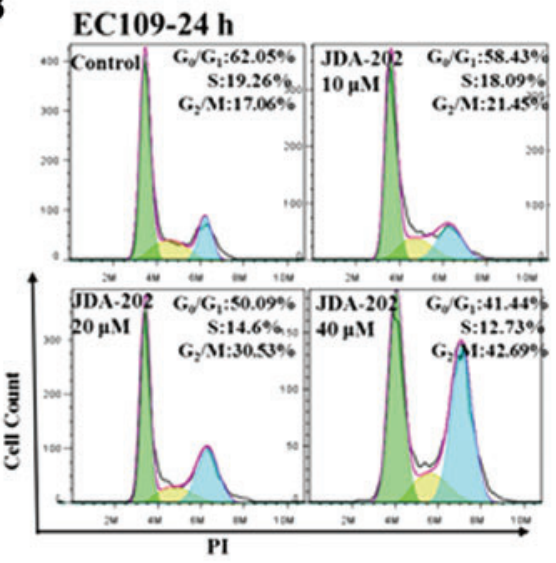

F

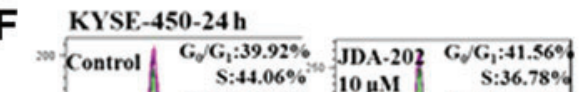

C

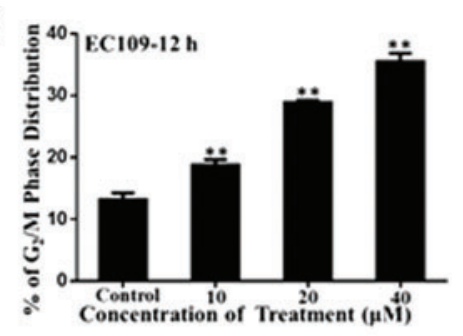

D

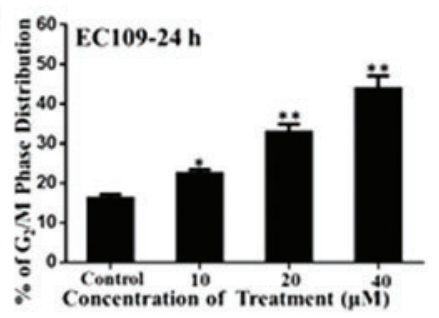

G

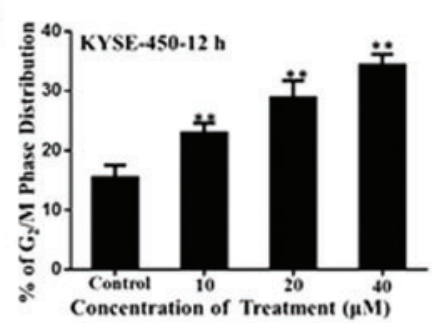

H

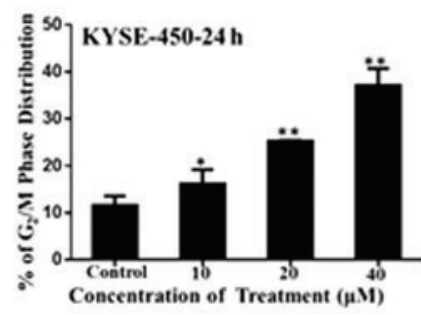

K

KYSE-450

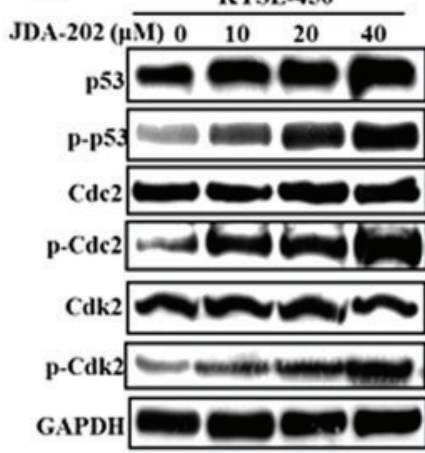

FIG. 4. The role of JDA-202 in cell cycle arrest in EC109 and KYSE-450 cells. EC109 and KYSE-450 cells were treated with JDA-202 at the indicated concentrations $(0,10,20$, and $40 \mu M)$. After treatment for 12 and $24 \mathrm{~h}$, cells were washed with PBS and fixed in $70 \%$ ethanol overnight at $4{ }^{\circ} \mathrm{C}$. The cells were then stained by PI and analyzed by flow cytometry in EC109 (A, B) and KYSE-450 (E, F) cells; $(\mathbf{C}, \mathbf{D})$ and $(\mathbf{G}, \mathbf{H})$ are the quantitation of those cell cycle distributions. EC109 and KYSE-450 cells were treated by JDA-202 (0, 10, 20, and $40 \mu M)$ for $24 \mathrm{~h}$; the expression levels (I, K) and quantitation ( J, L) of p53/phospho-p53 $\left(\mathrm{Ser}^{15}\right)$, Cdc2/phospho-Cdc2 $\left(\mathrm{Tyr}^{15}\right)$, and Cdk2/phospho-Cdk2 (Thr $\left.{ }^{160}\right)$ were detected by Western blot and Image J. Data are presented as means \pm SD. Three individual experiments were performed for each group. ${ }^{*} p<0.05, * * p<0.01$ as compared with the controls. PBS, phosphate-buffered saline. To see this illustration in color, the reader is referred to the web version of this article at www.liebertpub.com/ars 
JDA-202, as the indicated concentrations, the expression levels of Prx I, were measured by Western blot. We did not find any significant alteration of the total levels of Prx I in the cancer cells treated by JDA-202, compared with the controls (Fig. 6A). The protein expression of Prx I was then depleted, using three specific Prx I short interfering RNAs (siRNA\#1, siRNA\#2, and siRNA\#3; Fig. 6B, C). We found that downregulation of Prx I by Prx I siRNAs resulted in significant changes of cell apoptosis-related morphology, such as cell shrinkage and rounding up in EC109 cells (Fig. 6D). Suppression of Prx I also led to significant cell apoptosis in EC109 cells (Fig. 6E, H), similar to the previous findings (13). It is noteworthy that JDA-202 treatment did not further enhance the EC109 cell apoptosis rate, when the cells were pretreated with Prx I siRNA (Fig. 6E, H), indicating that the overexpressed Prx I or enhanced Prx I activity plays a key role in EC cell survival and Prx I is a major target of JDA-202 in EC cells. On the other hand, downregulation of Prx I in the normal esophageal HET-1A cells, treated with similar amounts of Prx I siRNA\#1, siRNA\#2, and siRNA\#3 (Fig. 6B, C), did not induce any significant cell apoptosis (Fig. 6F, G). These data suggest that overexpression of Prx I might increase the sensitivity of EC109 cells to JDA-202.

Furthermore, the expressions of Prx I in EC109 cells were upregulated by Prx I expression vector, whereas the null vector was used as the control. It was shown that Prx I levels were efficiently enhanced to about twofold (Fig. 6I, J), compared with the controls after $48 \mathrm{~h}$ transfection. The overexpression of Prx I significantly reversed JDA-202induced cell apoptosis (Fig. 6K, L). These findings further confirmed that the levels of Prx I played a major pathological effect on EC cell proliferation and specific targeting of Prx I with JDA-202 may be potentially used for the treatment of this malignant cancer.

ROS-related p38 activation mediates JDA-202induced cell apoptosis and cell cycle arrest

The MAPK signaling pathway, including the extracellular signal-regulated kinase (ERK), c-Jun N-terminal kinase (JNK), and p38 subgroups, plays an important role in regulating gene expression in eukaryotic cells and links extracellular signals to the machinery that controls fundamental cellular processes such as growth, proliferation, differentiation, migration, and apoptosis $(28,36)$. Then, we examined the effects of JDA-202 on the phosphorylation and total levels of different MAPKs subgroups. As shown in Figure 7A-D, the expression levels of total ERK, JNK, and p38 proteins were not affected by JDA-202. However, treatment of JDA-202 significantly and persistently increased phosphorylation of p38 at $\mathrm{Tyr}^{182}$, JNK at $\mathrm{Thr}^{183} / \mathrm{Tyr}^{185}$, and ERK at $\mathrm{Thr}^{202} / \mathrm{Tyr}^{204}$ in a concentration- and time-dependent manner (Fig. 7A-D). Notably, after pretreatment with $5 \mathrm{~m} M$ NAC, the upregulated phosphorylation of $\mathrm{p} 38$ at $\mathrm{Tyr}^{182}$, JNK at $\mathrm{Thr}^{183} / \mathrm{Tyr}^{185}$, and ERK at $\mathrm{Thr}^{202} / \mathrm{Tyr}^{204}$ was thoroughly reversed (Fig. 7E, F), indicating that the activation of MAPKs was dependent on JDA-202-induced ROS accumulation.

To verify which sub-MAPK pathway plays a major important role in JDA-202-induced cell cytotoxicity, EC109 cells were pre-incubated with $30 \mu M$ ERK inhibitor (PD98059), $30 \mu M$ JNK inhibitor (SP600125), or $4 \mu M$ p38 inhibitor (SB203580) $(9,24)$ for $4 \mathrm{~h}$ before JDA-202 treatment. As shown in Figure 7G, SB203580 decreased JDA-202-induced cell death, whereas PD98059 and SP600125 did not have significant effects. Furthermore, SB203580 also largely rescued JDA-202-induced loss of mitochondrial membrane potential (Fig. 7H, I). Correspondingly, SB203580 pretreatment significantly delayed the initiation of the $\mathrm{G}_{2} / \mathrm{M}$ arrest, elicited by JDA-202 (Fig. 7J, K). The percentage of the cells at $\mathrm{G}_{2} / \mathrm{M}$ phase in SB03580 plus $40 \mu M$ JDA-202 was $24.3 \%$, when compared with those with $40 \mu M$ JDA-202 treatment only (47.6\%), SB03580 only (24.1\%), and the control $(22.6 \%)$, respectively. After p38 expression was downregulated by p38 siRNA (Fig. 7L, M), JDA-202-induced cytotoxicity in EC109 cells was significantly reversed (Fig. $7 \mathrm{~N}$ ). Meanwhile, the levels of phospho-p70S6K (Thr ${ }^{389}$ ) and phospho-mTOR $\left(\mathrm{Ser}^{2448}\right)$, which had been reported to play an important role in the downstream activity of Prx I (13), were also decreased by JDA-202 in a concentration- and time-dependent manner (Fig. 7A-D). Together, these data indicate that p38 MAPK and p70S6K-mTOR signaling pathways play a key role in JDA202-induced cell apoptosis and $\mathrm{G}_{2} / \mathrm{M}$ phase arrest in EC109 cells, which may be associated with ROS accumulation.

\section{The anti-proliferative effect of JDA-202 on esophageal cancer xenograft model}

Based on the earlier findings, the effect of JDA-202 in esophageal cancer in vivo was further determined. Briefly, the EC109 cells-derived xenograft model was used by subcutaneously injecting the cells into BALB/c nude mice. JDA-202 $(20 \mathrm{mg} / \mathrm{kg}$, daily) was then intravenously injected, with paclitaxel (PTX $10 \mathrm{mg} / \mathrm{kg}$, every 3 day), $\beta$-cyclodextrin, or saline as the positive, solvent, or negative controls, respectively.

FIG. 5. The role of ROS in JDA-202-induced esophageal cancer cell death. Four esophageal cells were treated with JDA-202 for $12 \mathrm{~h}$. The levels of ROS and $\mathrm{H}_{2} \mathrm{O}_{2}(\mathbf{A}, \mathbf{B})$ were detected by flow cytometry. After pretreatment with or without $5 \mathrm{~m} M$ NAC or 1 or $2 \mathrm{U} / \mathrm{L}$ catalase for $2 \mathrm{~h}, \mathrm{EC} 109$ cells were treated with indicated concentrations of JDA-202 for $12 \mathrm{~h}$; then, the intracellular ROS was detected by a fluorescence microscope $(\mathbf{C}, \mathbf{F})$ or flow cytometry $(\mathbf{D}, \mathbf{E}, \mathbf{G}, \mathbf{H})$. (I) After pretreatment with or without $5 \mathrm{~m} M$ NAC or $2 \mathrm{U} / \mathrm{L}$ catalase for $2 \mathrm{~h}, \mathrm{EC} 109$ cells were treated with indicated concentrations of JDA-202 for $24 \mathrm{~h}$; cell viability was determined by MTT assay, and $\Delta \Psi_{m}$ was detected by flow cytometry (J) and quantitated (K). (L) After pretreatment with or without 1 or $2 \mathrm{U} / \mathrm{L}$ catalase for $2 \mathrm{~h}$, EC109 cells were treated with indicated concentrations of JDA-202 for $24 \mathrm{~h}$, and $\Delta \Psi_{m}$ was detected by a fluorescence microscope. After pretreatment with or without $5 \mathrm{~m} M$ NAC for $2 \mathrm{~h}$, EC109 cells were treated with indicated concentrations of JDA-202 for $24 \mathrm{~h}$, and the expression and quantitation of Bcl-2 and Bax (M, N) were detected by Western blot and Image J. Data are presented as means \pm SD. Three individual experiments were performed for each group. ${ }^{* *}, \#, \$ \$ p<0.01$, compared with the controls. $\Delta \Psi m$, mitochondrial membrane potential; NAC, N-acetylcysteine; ROS, reactive oxygen species. To see this illustration in color, the reader is referred to the web version of this article at www.liebertpub.com/ars 
A

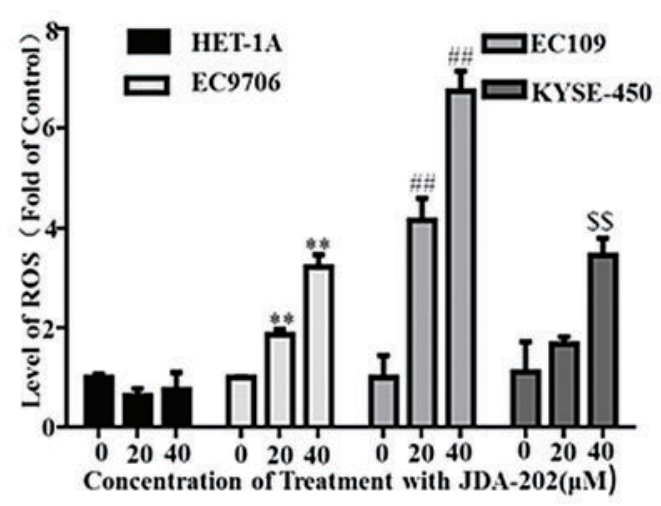

B

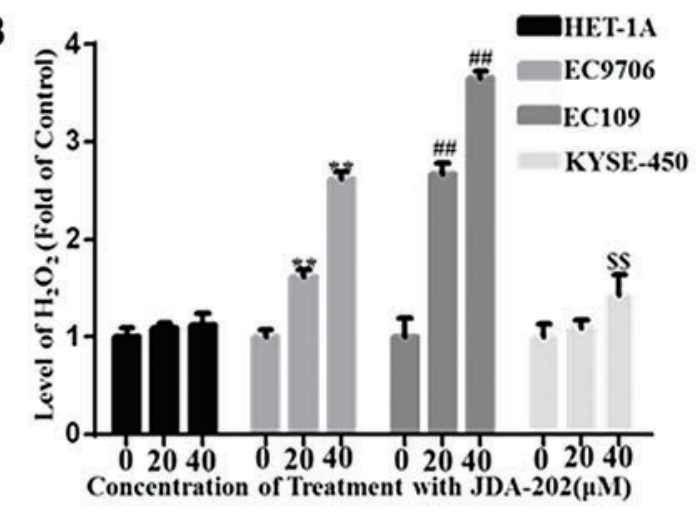

C

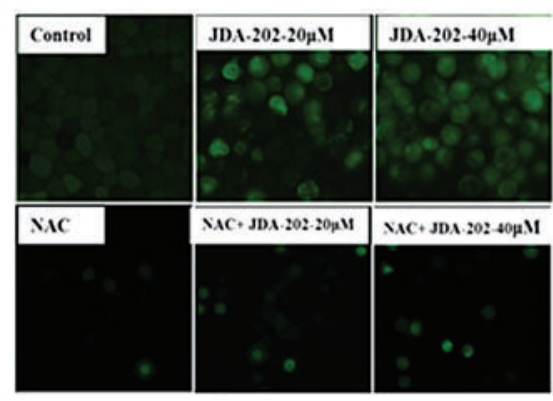

F

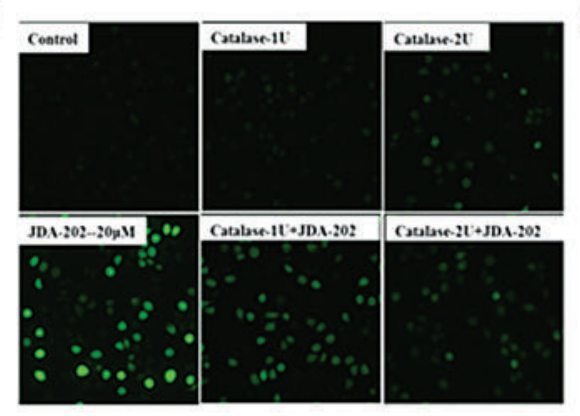

$1 \quad-$ CatalsectJDA-20
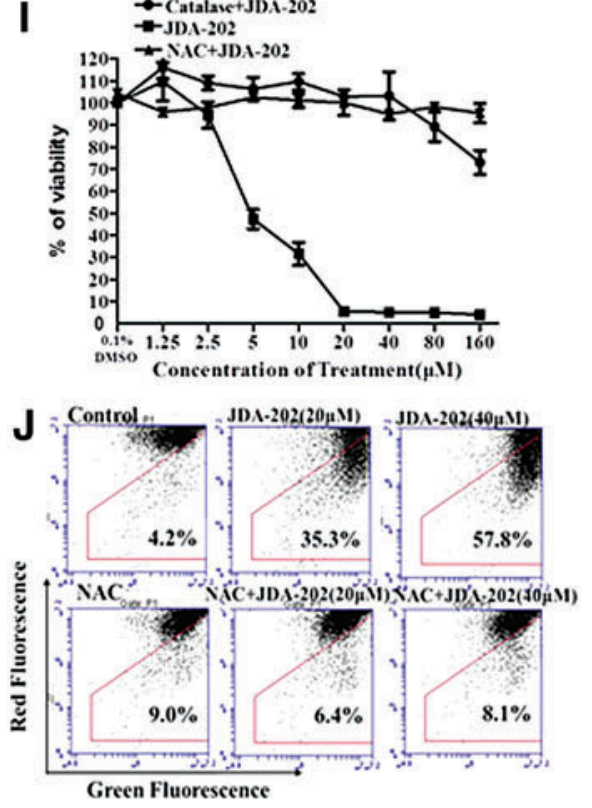

D

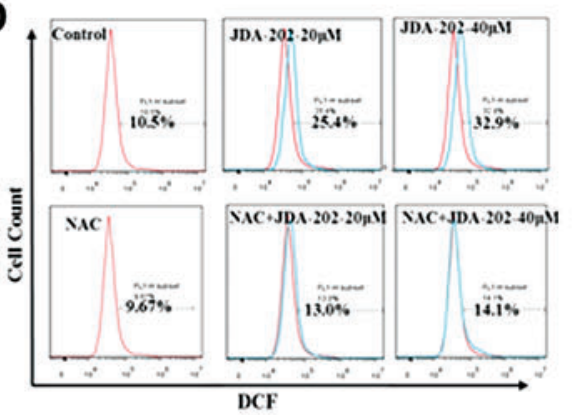

G

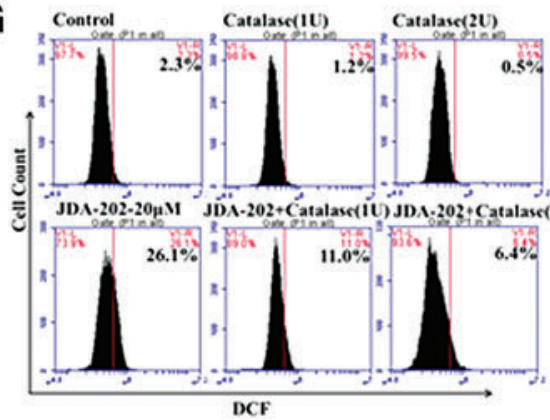

L

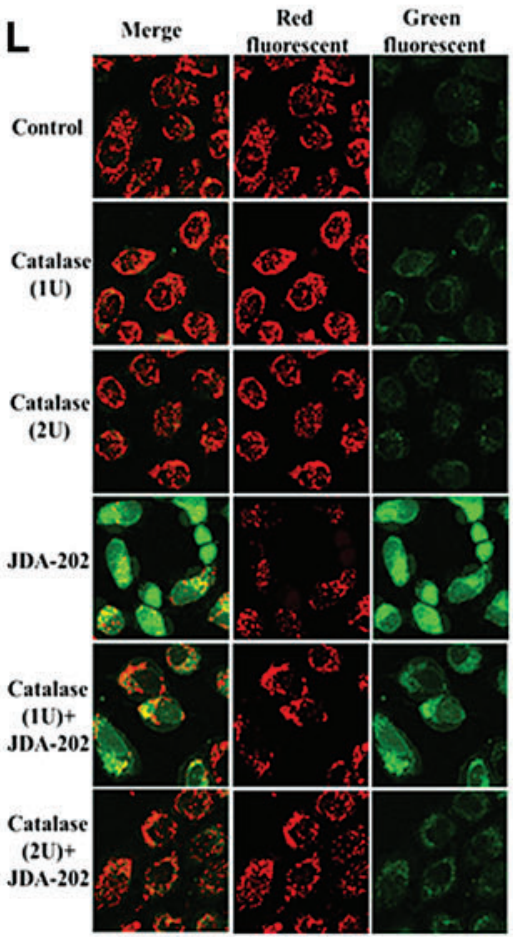

E

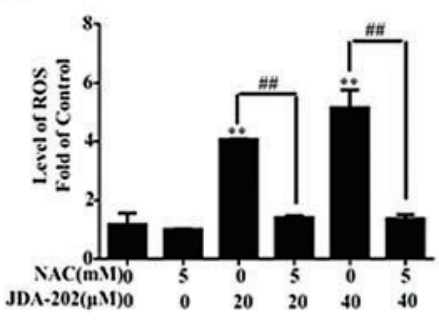

H

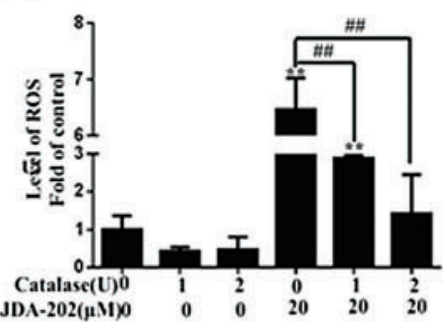

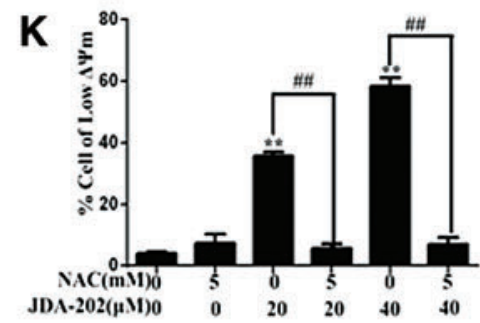

$\begin{array}{llllll}M & \mathrm{NAC}(\mathrm{mM}) & 0 & 5 & 0 & 5\end{array}$

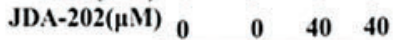

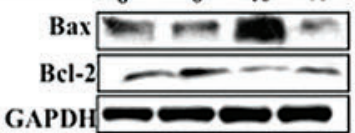

N

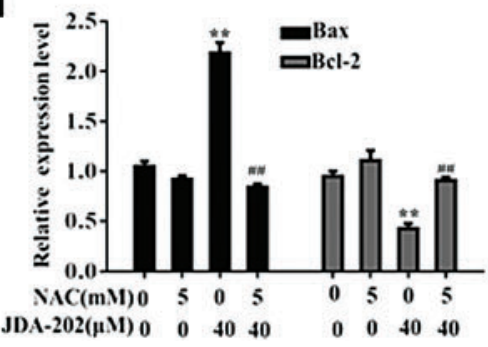


A

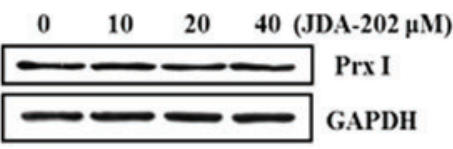

D

$\mathbf{E}$
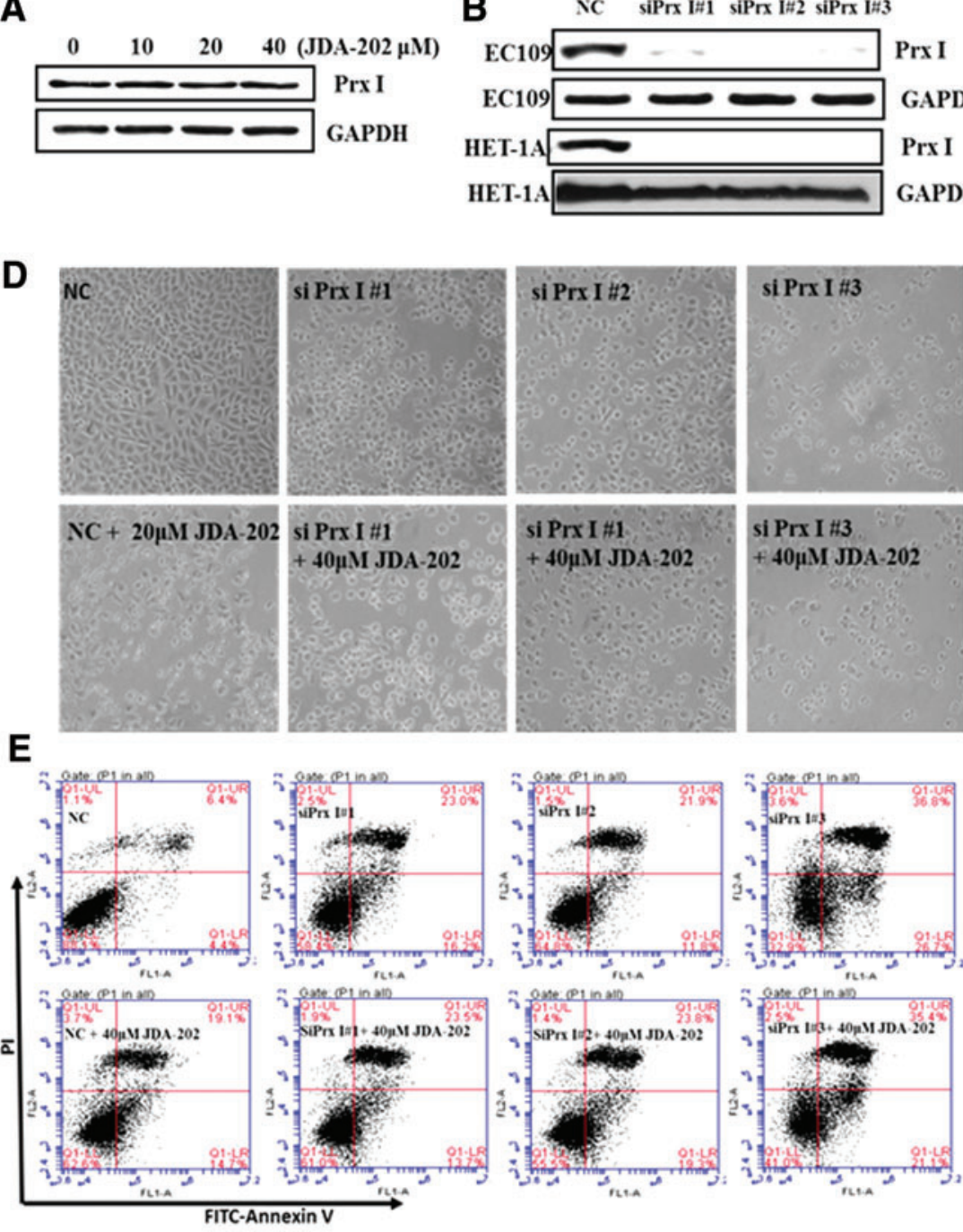

Prx I

GAPDH

Prx I

GAPDH

\section{C}

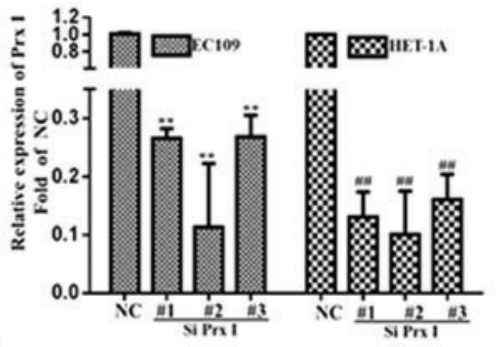

H
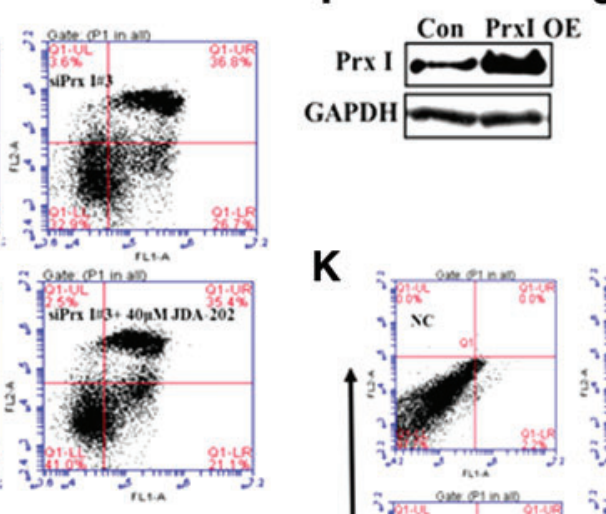

$\mathbf{F}$
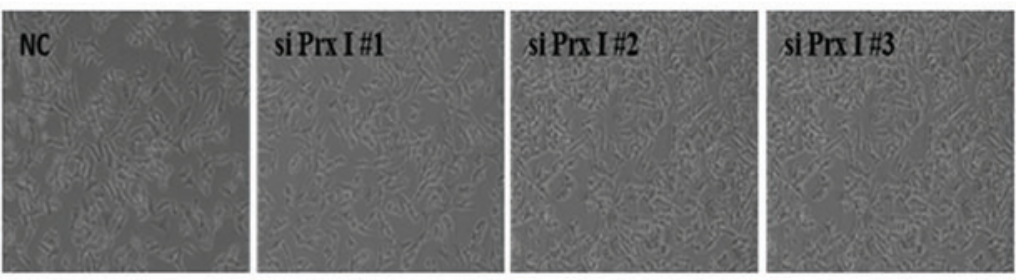

G
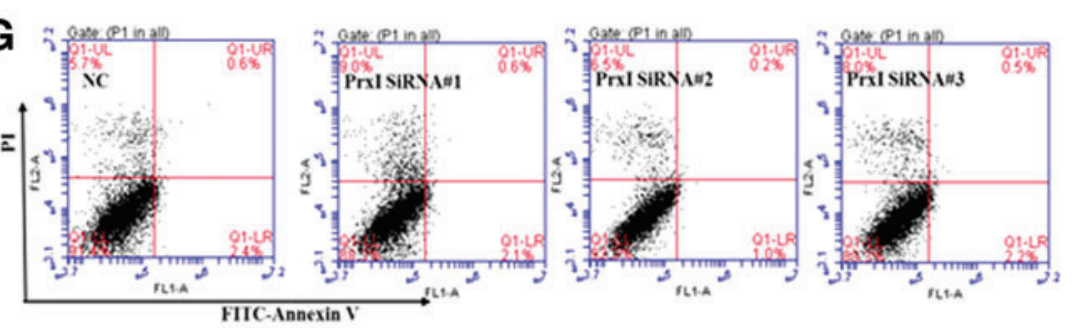

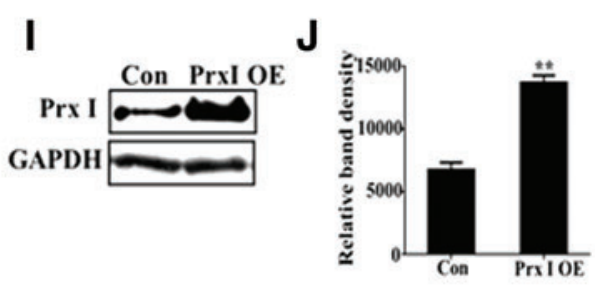

K
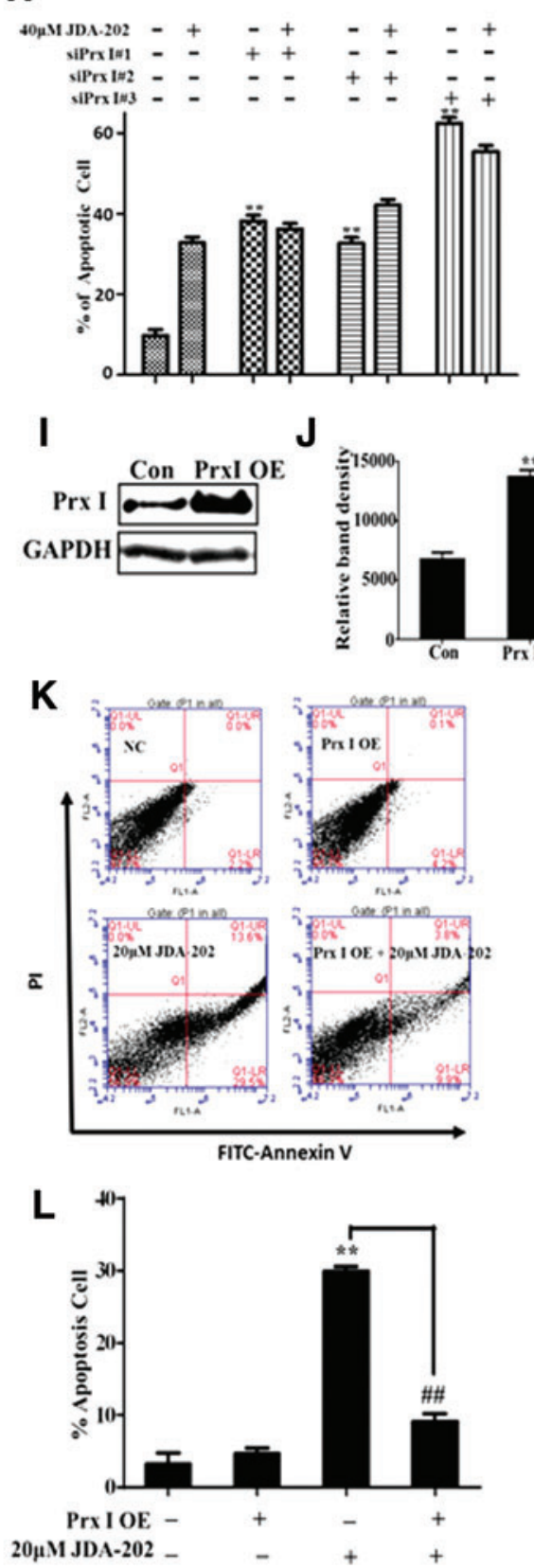

FIG. 6. Effects of Prx I levels on the cell death caused by JDA-202. (A) EC109 cells were treated with JDA-202 for $24 \mathrm{~h}$ with indicated concentrations, and the expression of Prx I was determined by Western blot. The representative expression (B) and quantitation (C) of Prx I after Prx I siRNA\#1, siRNA\#2, and siRNA\#3 interference for $48 \mathrm{~h}$ in EC109 and HET-1A cells. The letters on the left refer to the indicated cells, and the letters on the right refer to the detected proteins. Apoptosis-related cell morphologies (D) and apoptosis analysis and values $(\mathbf{E}, \mathbf{H})$ in EC109 cells after downregulation of Prx I combined with or without JDA-202 treatment. Cell morphologies (F) and apoptosis values (G) in HET-1A cells after downregulation of Prx I. (I, J) Overexpression and quantitation of Prx I in EC109 cells. (K, L) Overexpression of Prx I in EC109 cells almost completely reversed cell apoptosis caused by JDA-202. Data are presented as means \pm SD. Three individual experiments were performed for each group. ${ }^{*} p<0.01$ compared with the controls. ${ }^{\# \#} p<0.01$, when the JDA202 plus Prx I OE group is compared with the JDA-202 group. siRNA, short interfering RNA. To see this illustration in color, the reader is referred to the web version of this article at www.liebertpub.com/ars 
During the 21-day treatment, the mouse body weight was monitored and the tumor size was measured and recorded every 3 days. We found that administration of JDA-202 did not cause obvious body weight loss, compared with the three controls, indicating the less side effects of JDA-202 on the nude mice (Fig. 8D). The average tumor volume after JDA202 treatment was significantly decreased in comparison with the controls. At the end of therapy, the average tumor weight after JDA-202 treatment was decreased to $38.3 \%$, compared with those in saline (100\%) and $\beta$-cyclodextrin (112\%) groups (Fig. 8A-C, E), although treatment with JDA-202 appeared less therapeutic activity than that with PTX.

Histopathological examination of the liver, kidney, lung, heart, and spleen revealed no signs of toxicity after JDA-202 treatment (Supplementary Fig. S6). In addition, no obvious adverse effects with regard to general health were observed. These data indicate that JDA-202 was efficacious in inhibiting the EC tumor growth in vivo without obvious global toxicity, showing its potential therapeutic effect in this cancer.

\section{Discussion}

EC is an aggressive malignant solid tumor with poor prognosis. Surgery in combination with chemotherapy or radiotherapy is currently a main approach for the treatment of EC. It is well known that many solid tumors have elevated ROS, which then activate specific oncogenes $(35,62)$, thus enhancing proliferation or other malignant phenotypes, whereas the excess higher levels of ROS also render the cancer susceptible to the increased ROS. Therefore, targeting the enzymes that eliminate elevated ROS has been suggested to be a promising strategy to selectively induce cancer cell death. Prx I has been reported to be overexpressed in various malignant solid tumors and cell lines $(7,10,19,21,22,39$, $47,48,52)$, including esophageal cancer cell lines $(13,16$, 41). Higher Prx I levels in patients with pancreatic cancer are associated with poor prognosis and reduced overall patient survival (6). Overexpression of Prx I in human lung cancer cells resulted in the enhanced clonogenic survival of irradiated cells and suppressed ionizing radiation-induced JNK activation and apoptosis (27). Conversely, downregulation of Prx I expression delayed the tumor cell growth, increased caspase 3 activity in HCC (1), and reduced tumor vascular formation and function in prostate tumor cells (48). Those results suggest the significance of Prx I expression levels on the tumor progression. Previous studies $(41,42,44,65)$ also reported that the upregulation of Prx I promoted tumorigenesis in EC, and knockdown of this protein induced EC cell apoptosis (13). However, whether Prx I could be regarded as a therapeutic target for EC remains controversial. One earlier paper reported that the histone deacetylase inhibitor FK228 showed an antitumor effect against T.Tn and TE2 esophageal cancer cells, partially through activating Prx I by modulating acetylation of histones of the Prx I promoter. The precise mechanism of Prx I activation by FK228 requires further studies (17). The present study indicated that Prx I was, indeed, overexpressed in human EC tissues and in three indicated EC cell lines, associated with ability of clone formation and proliferation, whereas other well-known antioxidant proteins (Prx II- Prx VI, SOD, catalase, and Trx) did not show any significant alterations. Furthermore, downregulation of Prx I caused remarkable changes of apoptotic morphology and high apoptosis rate in EC109 cells. Therefore, our findings, for the first time, proved that Prx I could be regarded as a potential druggable target for EC treatment.

Earlier studies reported that miR-510 suppressed migration of human breast cancer cells by directly binding to the $3^{\prime}$ untranslated region (UTR) of Prx I and blocking its protein expression (14). AMRI-59, a potent small-molecule inhibitor of Prx I, preferentially induced apoptosis of human non-small cell lung cancer A549 cells (63). Natural product Adenanthin has been reported to target Prx I/II, thus resulting in HCC cell death (18). In the current study, we found that one natural product from our compound library, JDA-202 exhibited a strong and direct inhibitory effect on Prx I in vitro. Compared with Adenanthin, which can target both Prx I and Prx II, JDA202 was much more selective to Prx I than Prx II. Our findings in enzyme assay, binding affinity assay, and molecular docking also proved, for the first time, that both Phe50 and Arg 128 residues of Prx I are crucial for Prx I activity and the direct interaction of JDA-202 with these two residues.

JDA-202 exhibited more potent inhibition against the tested EC cells and good selectivity. Furthermore, compared with Jaridonin, another compound reported previously by our group (33), JDA-202 was twice more potent than Jaridonin in terms of Prx I inhibition in vitro and cytotoxicity. Further studies showed that the cytotoxicity caused by JDA-202 was associated with $\mathrm{H}_{2} \mathrm{O}_{2}$-induced cell apoptosis. However, JDA202 treatment was less cytotoxic toward normal esophageal cell line HET-1A. On the other hand, downregulation of Prx I induced by siRNA in this cell line did not lead to cell apoptosis, which is different from those in EC cells. These

FIG. 7. JDA-202-induced ROS accumulation results in activation of MAPK family in EC109 cells. EC109 cells were treated with JDA-202 (10, 20, and $40 \mu M)$ for $24 \mathrm{~h}$, Phospho- and total forms of ERK, p38 and JNK, mTOR as well as Phosphop70S6K were analyzed by Western blot and quantitated (A, C). EC109 cells were treated with $40 \mu M$ JDA-202 for 6, 12 , or 24 h; the proteins described earlier were analyzed by Western blot and quantitated (B, D). After pre-incubation with or without $5 \mathrm{~m} M \mathrm{NAC}$, EC109 cells were treated with $40 \mu M$ JDA-202 for $24 \mathrm{~h}$; Phospho- and total forms of ERK, p38, and JNK were analyzed by Western blot and quantitated (E, F). (G) EC109 cells were incubated in medium containing p38, ERK, and JNK inhibitors: SB203580, PD98059, and SP600125, respectively, followed by treatment with $40 \mu M$ JDA-202 for 24 h; cell viability was determined by Trypan blue assay and expressed as percentage of the control. EC109 cells were incubated in medium containing SB203580 followed by treatment with $40 \mu M$ JDA-202 for $24 \mathrm{~h} ; \Delta \Psi m(\mathbf{H}, \mathbf{I})$ and cell cycle distribution $(\mathbf{J}, \mathbf{K})$ were detected by flow cytometry. (L, M) The expression levels and quantitation of p38 after p38 siRNA (20 or $50 \mathrm{n} M)$ interference for $48 \mathrm{~h}$ in EC109 cells. After 338 siRNA treatment, EC109 cells were treated with JDA-202 for $24 \mathrm{~h}$, and cell viability was determined by MTT assay (N). Data are presented as means \pm SD. Three individual experiments were performed for each group. ${ }^{* *}, \#{ }^{\prime} p<0.01$ compared with the controls. ERK, extracellular signal-regulated kinase; JNK, c-Jun N-terminal kinase; MAPK, mitogen-activated protein kinase. To see this illustration in color, the reader is referred to the web version of this article at www.liebertpub.com/ars 


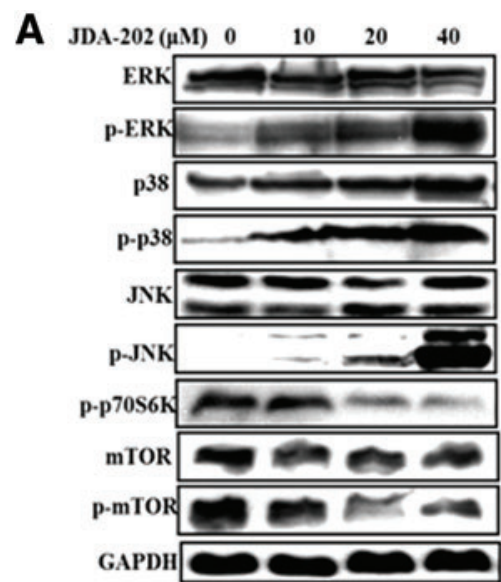

E

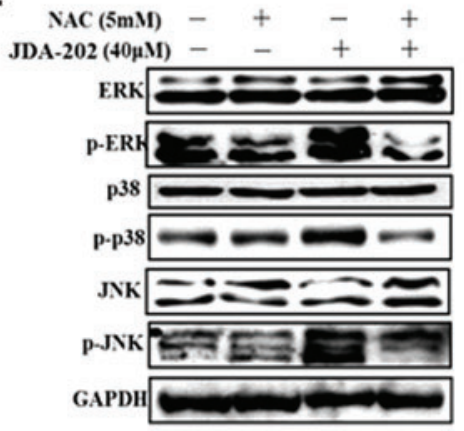

H

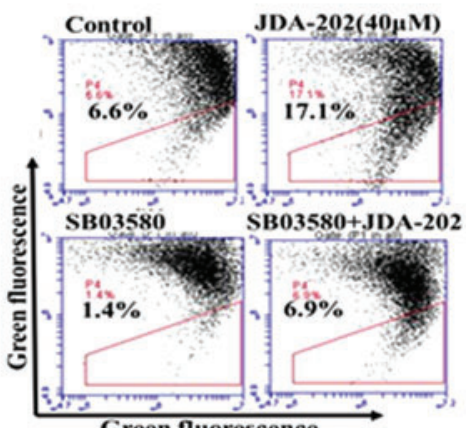

$\mathbf{K}$

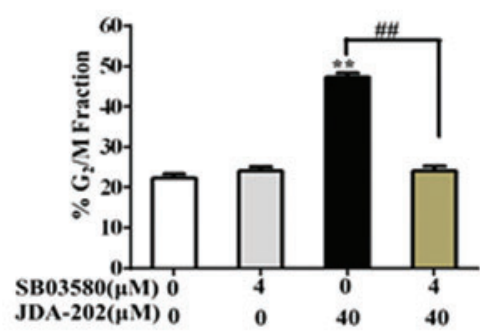

B

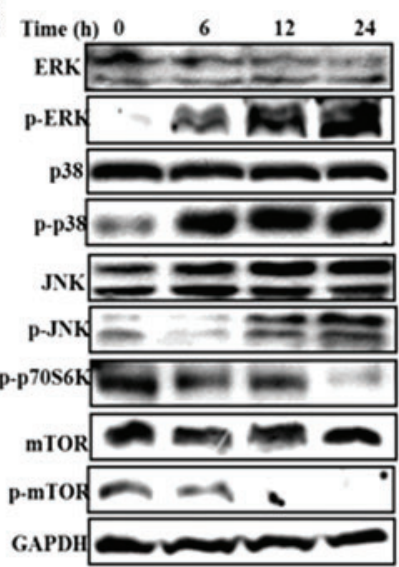

$\mathbf{F}$

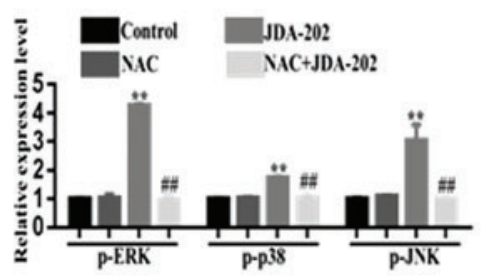

G
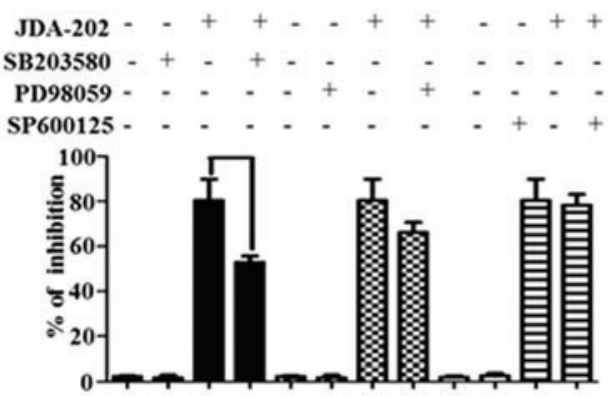

$\mathbf{J}$
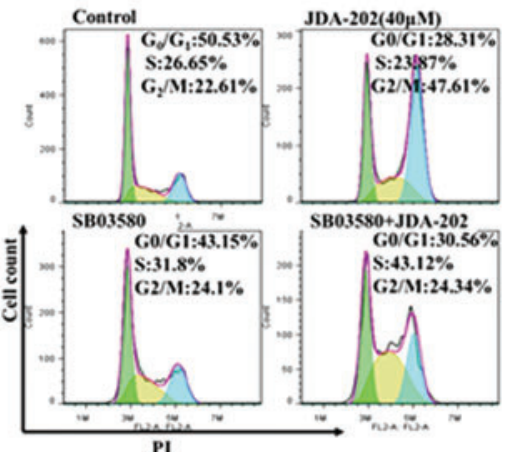

N

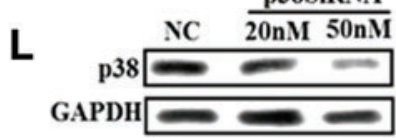
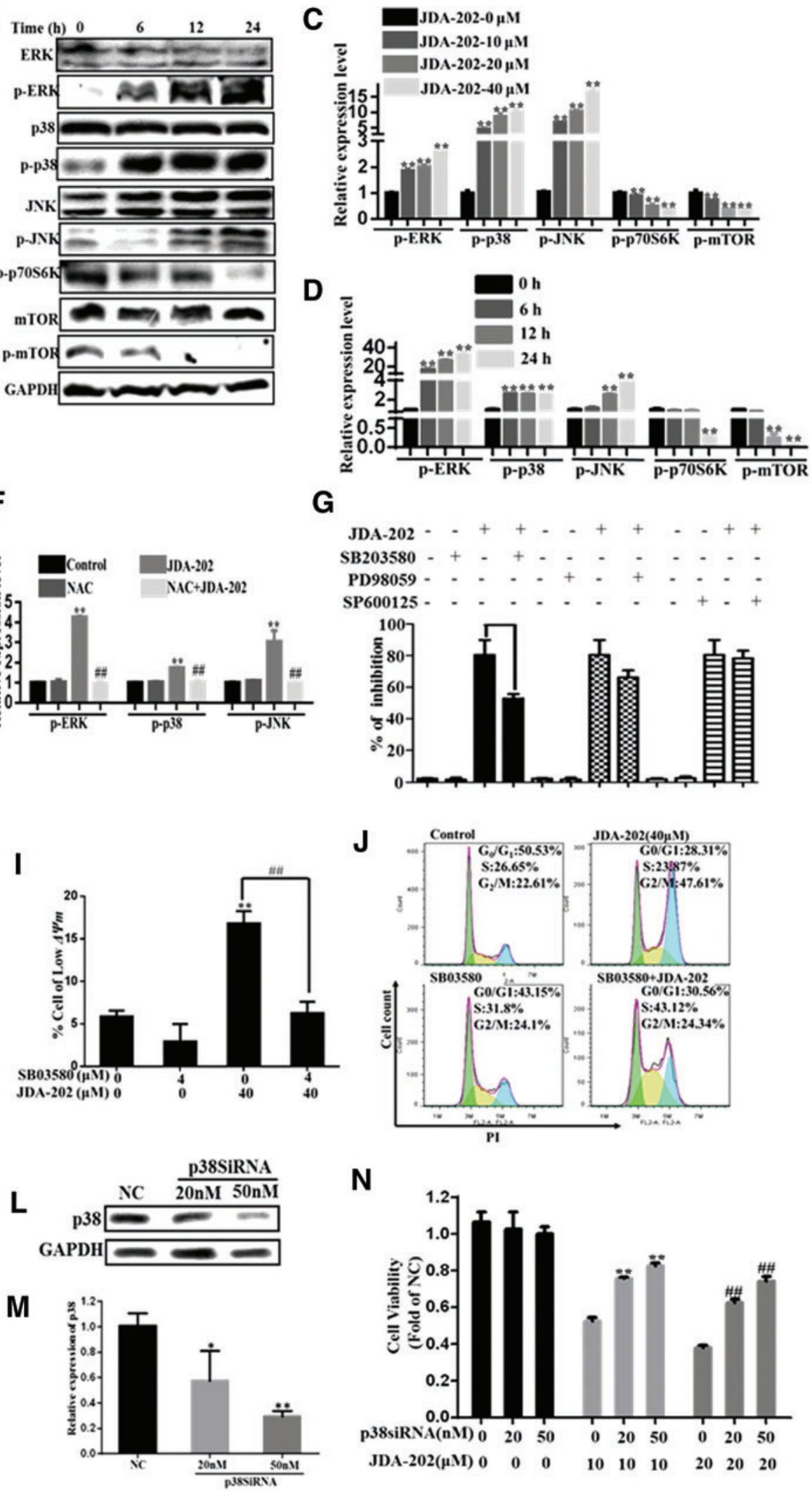


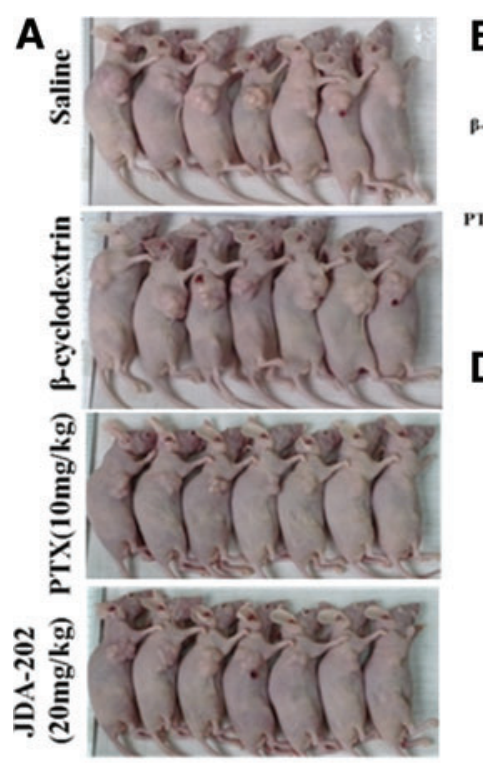

E

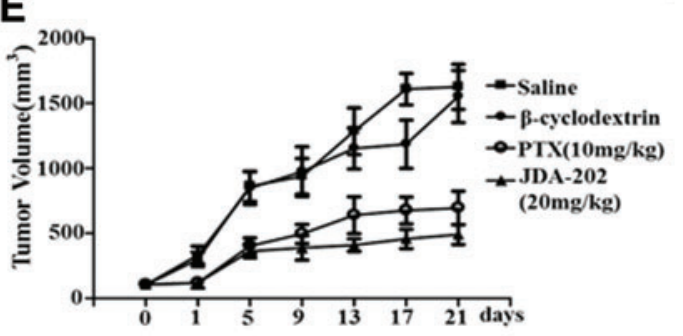

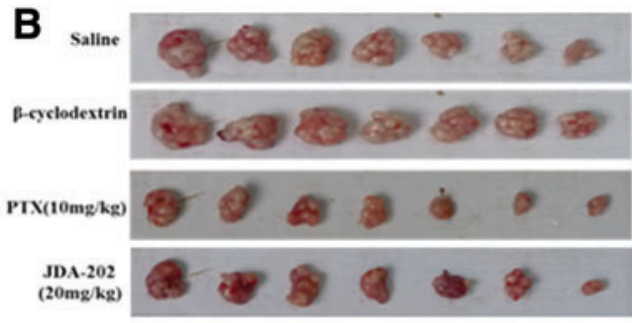

D

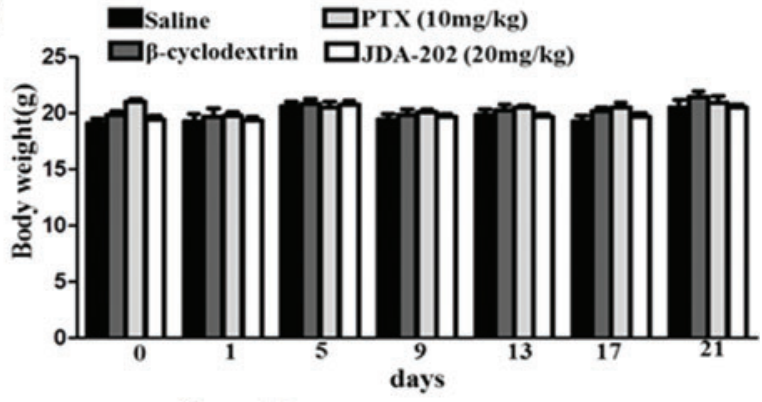

C
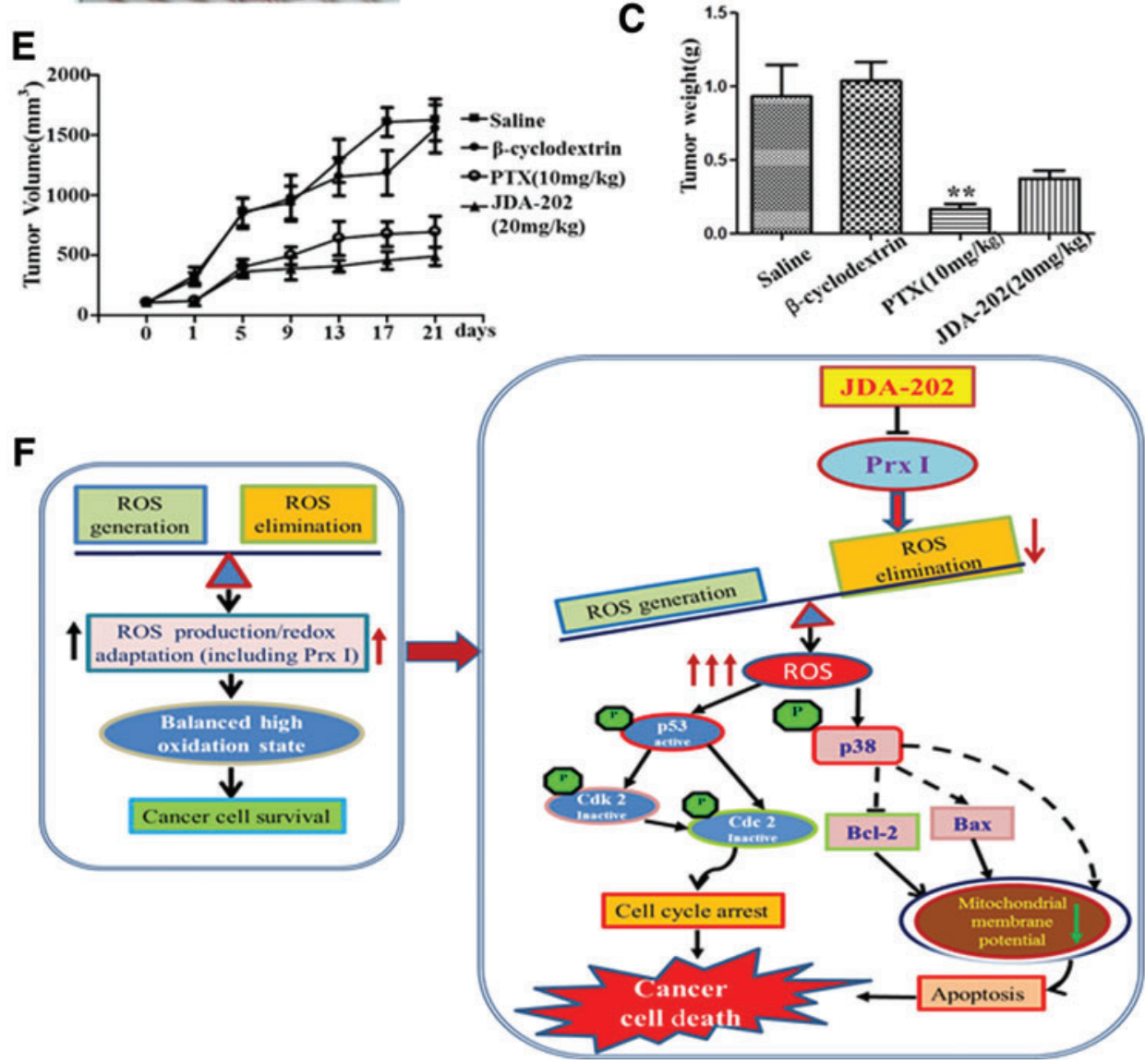

FIG. 8. The anti-tumor growth effect of JDA-202 on xenograft model-bearing EC109 cells. EC109 cells were transplanted subcutaneously to the right sides of BALB-C nude mice for 1 week. Mice were intravenously injected with saline (vehicle, daily), $\beta$-cyclodextrin (solvent, daily), or PTX $(10 \mathrm{mg} / \mathrm{kg}$, once every 3 day) and JDA-202 (20 mg/kg, daily) for 21 days. (A, B) The animals with tumor burden and the tumor masses were photographed at the end of treatment (21 days). (C) The average tumor weights with the indicated treatments. (D) The mouse body weights were measured every 3 days and expressed, followed by indicated treatments. (E) The tumor volumes were measured every 3 days, followed by indicated treatments. Data are presented as means $\pm \mathrm{SD}\left(n=7\right.$ for each group). ${ }^{*} p<0.01$ compared with the controls. (F) Proposed mechanisms for JDA-202-induced cell death in esophageal cancer cells through targeting Prx I. JDA-202 inhibits Prx I activity both in vivo and in vitro and interrupts balanced ROS in cancer cells through decreasing the ability of ROS elimination (The two parallel arrows in the left frame with a different color indicated the paralleled enhanced ROS generation and redox adaptation [including Prx I] in cancer cells, which represent a new balance of ROS metabolism.). Furthermore, JDA-202 induces ROS accumulation that activates p38 and causes Bax upregulation and Bcl-2 downexpression, leading to the loss of mitochondrial membrane potential and induction of apoptosis. In addition, JDA-202 activates p53 and leads to cell cycle arrest. PTX, paclitaxel. To see this illustration in color, the reader is referred to the web version of this article at www.liebertpub.com/ars 
findings suggest that a compensatory mechanism may exist in HET-1A cells, compared with EC cells (46).

MAPK family is a major sub pathway influenced by Prx I or $\operatorname{ROS}(15,32)$. Others reported that Prx I regulated ASK1mediated p38 and the JNK signaling pathway (26). More results showed that suppression of Prx I decreased active p38MAPK localized in cell protrusions and inhibited the invasiveness of pancreatic ductal adenocarcinoma (PDAC) cells (53). In this article, we demonstrated that JDA-202 increased the phosphorylation of ERK, p38, and JNK, which was abrogated by NAC. The pro-apoptotic effect of JDA-202 mainly depends on the activated p38 pathway. These findings suggest that JDA-202 induces EC109 cell apoptosis, mainly via ROS-related p38 activation.

Taken together, in the current study, we demonstrated, for the first time, that the natural product JDA-202 promoted EC cell apoptosis and decreased tumor growth by targeting the over-activated antioxidant protein Prx I, which is mainly associated with ROS-related activation in the p38MAPK signaling pathway, mitochondria injury, cell cycle $G_{2} / M$ phase arrest, and apoptosis (Fig. 8F). Our findings highlight that JDA202 may serve as a promising candidate for the treatment of EC through targeting the overexpressed Prx I in human EC cells.

\section{Materials and Methods}

\section{Extraction and isolation of JDA-202}

JDA-202 was isolated and purified from I. rubescens (Labiatae). Briefly, the air-dried and powdered leaves of Rabdosia Rubescens $(6.0 \mathrm{~kg})$ were extracted with $95 \% \mathrm{EtOH}$ $(60,000 \mathrm{ml} \times 2)$ at $50^{\circ} \mathrm{C}$ for $3 \mathrm{~h}$. After using a vacuum to remove about $95 \%$ of the solvent, the residue was partitioned in water and extracted with ethyl acetate $($ EtOAc, $5000 \mathrm{ml} \times 3$ ). The EtOAc extract ( $240 \mathrm{~g}$ ) was subjected to silica gel column chromatography (CC). Then, $\mathrm{CHCl}_{3}, \mathrm{CHCl}_{3}-\mathrm{Me}_{2} \mathrm{CO}$ (10:1, $5: 1,3: 1,1: 1)$, and $\mathrm{Me}_{2} \mathrm{CO}$ were used to elute the CC. About $10 \mathrm{~g}$ compound JDA-202 was obtained from the $\mathrm{CHCl}_{3}$ $\mathrm{Me}_{2} \mathrm{CO}$ (3:1) eluting fraction after repeated silica gel $\mathrm{CC}$ separation and recrystallization in EtOAc.

\section{Chemicals and reagents}

The chemical structure of this JDA-202 is shown in Figure 2A. The purity was confirmed to be higher than $99 \%$ by HPLC. IR, ${ }^{1} \mathrm{H}$ NMR, ${ }^{13} \mathrm{C}$ NMR, and MS data of JDA-202 are in the following order. JDA-202: white prismatic crystals (EtOAc recrystallization), m.p.: $216-218^{\circ} \mathrm{C}$; IR $\left(\mathrm{KBr}, \mathrm{cm}^{-1}\right): 3426$, 2939, 1718, 1644, 1263, 1106, 1032, 992; ${ }^{1} \mathrm{H}$ NMR (DMSO$\left.\mathrm{d}_{6}\right): 5.78,5.36$ (each 1H, s, H-17), $5.01(1 \mathrm{H}, \mathrm{s}, \mathrm{H}-20), 4.49(1 \mathrm{H}$, $\mathrm{s}, \mathrm{H}-14 \alpha), 4.41(1 \mathrm{H}, \mathrm{q}, \mathrm{J}=8.8 \mathrm{~Hz} \mathrm{H}-11 \alpha), 3.98(1 \mathrm{H}, \mathrm{d}$, $\mathrm{J}=2.8 \mathrm{~Hz}, \mathrm{H}-7 \beta), 3.32(3 \mathrm{H}, \mathrm{s}, \mathrm{H}-21), 2.80(1 \mathrm{H}, \mathrm{d}, \mathrm{J}=9.2 \mathrm{~Hz}, \mathrm{H}-$ $13 \alpha), 2.66(1 \mathrm{H}, \mathrm{t}, \mathrm{J}=12.6 \mathrm{~Hz}, \mathrm{H}-6 \beta), 2.58(1 \mathrm{H}, \mathrm{dt}, \mathrm{J}=14.0$, $9.2 \mathrm{~Hz}, \mathrm{H}-12 \alpha), 1.98(1 \mathrm{H}, \mathrm{d}, \mathrm{J}=12.0 \mathrm{~Hz}, \mathrm{H}-1 \alpha), 1.57(1 \mathrm{H}, \mathrm{m}, \mathrm{H}-$ $6 \alpha), 1.42(1 \mathrm{H}, \mathrm{d}, \mathrm{J}=13.2 \mathrm{~Hz}, \mathrm{H}-3 \alpha), 1.36$ (2H, br s, H-2), 1.34 $(1 \mathrm{H}, \mathrm{dd}, \mathrm{J}=12.0,4.0 \mathrm{~Hz}, \mathrm{H}-1 \beta), 1.25(1 \mathrm{H}, \mathrm{dd}, \mathrm{J}=14.0,8.4 \mathrm{~Hz}$,

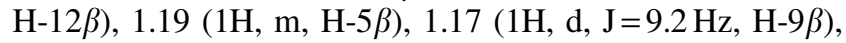
1.07 (1H, dt, J=13.2, 4.0 Hz, H-3 $\beta), 0.93$ (3H, s, H-19), 0.90 (3H, s, H-18); ${ }^{13} \mathrm{C}$ NMR (DMSO-d 6 ): 206.0 (C-15), 152.6 (C16), 116.1 (C-17), 100.6 (C-20), 69.7 (C-14), 65.3 (C-7), 63.3 (C-11), 57.5 (C-8), 56.4 (C-9), 55.1 (C-21), 48.6 (C-5), 42.7 (C-13), 42.0 (C-12), 40.6 (C-3), 39.6 (C-10), 33.9 (C-4), 32.9 (C-18), 30.3 (C-1), 24.5 (C-6), 20.9 (C-19), 18.0 (C-2);
ESI-HRMS: $m / z$ cacld. for $\mathrm{C}_{21} \mathrm{H}_{30} \mathrm{O}_{5}[\mathrm{M}+\mathrm{Na}]^{+}:$385.1991, found 385.1994.

The representative results of ${ }^{1} \mathrm{H}$ NMR and ${ }^{13} \mathrm{C}$ NMR of JDA-202 are shown in Supplementary Fig. S1. The compound was dissolved in dimethyl sulfoxide (DMSO) with $1 \times 10^{4} \mu \mathrm{M} / \mathrm{L}$ as stock solution and diluted according to experimental requirement with a final DMSO concentration less than $0.1 \%(\mathrm{~V} / \mathrm{V})$. The structures of Oridonin, Jaridonin (33), and Adenanthin (31) are also shown in Supplementary Figure S2.

NAC was purchased from Beyotime Institute of Biotechnology (Jiangsu, China). ERK inhibitor (PD98059), JNK inhibitor (SP600125), and p38 inhibitor (SB203580) were purchased from Selleck Chemicals (Houston, TX). Mouse monoclonal antibodies against p53, Bcl-2, and Bax were purchased from Santa Cruz Biotechnology (Santa Cruz, CA). Rabbit monoclonal antibodies against phospho-p53 ( $\left.\operatorname{Ser}^{15}\right)$, Cdc2, phospho-Cdc2 $\left(\mathrm{Tyr}^{15}\right), \mathrm{Cdk} 2$, or phospho-Cdk2 $\left(\mathrm{Thr}^{160}\right)$ were from Signalway Antibody, Inc. (Pearland, TX). Rabbit polyclonal antibodies against $\mathrm{p} 38$, phospho-p38 $\left(\mathrm{Tyr}^{182}\right)$, or JNK and mouse monoclonal phospho-JNK ( $\mathrm{Thr}^{183} / \mathrm{Tyr}^{185}$ ) antibody were obtained from Zhongshan Golden Bridge Biotechnology Co., Ltd. (Beijing, China). Rabbit monoclonal antibodies against Prx I, Prx II, and Prx III were from Epitomics (Hangzhou, China); rabbit polyclonal antibodies against Prx IV, V, and VI were from proteintech (Wuhan, China); rabbit polyclonal Trx antibody was from Abgent Biotech (Suzhou, China); and SOD1 was from Wanleibio (Shenyang, China). Rabbit monoclonal antibodies against ERK, phospho-ERK $\left(\mathrm{Thr}^{202} / \mathrm{Tyr}^{204}\right)$, caspase-7, caspase-3, PARP, mTOR, phospho-mTOR ( $\mathrm{Ser}^{2448}$ ), and phosphop70S6K $\left(\mathrm{Thr}^{389}\right)$, as well as mouse monoclonal caspase-9 antibody were purchased from Cell Signaling Technology.

\section{Cell lines}

Human esophageal cancer cell lines EC109, EC9706, and KYSE-450 were obtained from Cell Bank of the Chinese Academy of Sciences (Shanghai, China). Human immortalized normal esophageal epithelial cell HET-1A was a gift from the First Affiliated Hospital of Zhengzhou University, which was purchased from the American Type Culture Collection (Manassas, VA). EC109 cell line is a well-differentiated human squamous cell carcinoma cell line, and EC9706 is a poorly differentiated human squamous cell carcinoma cell line (33). KYSE-450 is a well-differentiated human squamous cell carcinoma cell line (49). Human glioblastoma cell line SHG44 and human breast cancer cell line MCF-7 were purchased from the State Key Laboratory of Molecular Oncology, Chinese Academy of Medical Sciences (Beijing, China).

Detailed Methods, including cell culture, the description of MTT (3-[4, 5-dimethylthiazol-2-yl]-2, 5-diphenyltetrazolium bromide) assay, Trypan blue exclusion method, ROS assay, cell apoptosis assay, cell cycle assay, and $\Delta \Psi_{m}$ analysis, were described in our previous studies $(33,34)$.

\section{Cell growth curve and colony formation assay}

Cellular proliferation characteristic of the cell lines was determined with a cell growth curve and a colony formation assay. Briefly, esophageal cells $\left(1 \times 10^{3}\right.$ cells/well $)$ were cultured into a 96-well plate for indicated time points $(1,2,3$, 4 , and 5 days) and absorbance at wavelength of $490 \mathrm{~nm}$ for 
each well was simultaneously measured after MTT assay at the end of the time points. The growth curves were drawn according to the optic density values versus days.

Cell clone formation test was performed, as previously reported (59). The cells ( 500 cells/well) were placed in a six-well plate and cultured for 12 days. After the culture medium was washed away, the cells were washed twice with phosphatebuffered saline (PBS, pH 7.4: $2 \mathrm{mM} / \mathrm{L} \mathrm{KK_{2 }} \mathrm{PO}_{4}, 10 \mathrm{~m} M / \mathrm{L}$ $\mathrm{Na}_{2} \mathrm{HPO}_{4}, 2.7 \mathrm{mM} / \mathrm{L} \mathrm{KCl}, 137 \mathrm{~m} M / \mathrm{L} \mathrm{NaCl}$ ), fixed for $20 \mathrm{~min}$ in cold methanol, and stained for $30 \mathrm{~min}$ at $37^{\circ} \mathrm{C}$ with crystal violet staining. The number of clones was calculated under an inverted microscope.

\section{$R N A$ isolation and quantitative real-time polymerase chain reaction analysis}

The intracellular total RNA was isolated from cultured EC109, EC9706, KYSE-450, and HET-1A cells, using U1trapure RNA Kit ( $C W$ biotech). The purity of the isolated RNA was determined by measuring UV absorption of each sample with comparable A260/A280 ratios. One microgram total RNA was reverse transcribed in a $20 \mu$ l reaction system, using Revert Aid first-strand cDNA Synthesis Kit (Thermo Scientific), according to the manufacturer's instruction. Amplification and detection of mRNA expression was performed by quantitative real-time PCR with $0.5 \mu \mathrm{l}$ cDNA in FastStart Universal SYBR Green Master (Roche), using LightCycler ${ }^{\circledR}$ 96 Real-Time PCR System (Roche). The specificity of the primer pairs used for human Prx I-VI, GPx, Trx, catalase, SOD1 $(7,56)$, and $\beta$-actin (listed in Supplementary Table S2) was initially tested by primer-BLAST and then synthesized by Liuhe Huada Gene Technology Company (Beijing, China).

\section{Immunohistochemistry assay}

Tissue sections $(5 \mu \mathrm{m})$ of human ESC from the First Affiliated Hospital of Zhengzhou University were deparaffinized with xylene and immersed in a graded series of ethanol. Before the tissue collection, the clinical protocol was approved by the ethics review board of the First Affiliated Hospital of Zhengzhou University. Informed written consents were obtained from the patients. Every specimen was handled anonymously, according to the ethical and legal standards. Afterward, the sections were incubated with $3 \%$ peroxide-methanol for $20 \mathrm{~min}$ at room temperature, for endogenous peroxidase ablation, then rinsed $(3 \times 5 \mathrm{~min})$ in PBSTx (PBSTx: $0.01 M$ PBS, $0.05 \%$ BSA, $0.0015 \%$ Triton X-100), and finally blocked with 5\% BSA. The sections were then incubated overnight with monoclonal anti-Prx I antibody at $4^{\circ} \mathrm{C}$. After washing three times in PBS, the sections were incubated with secondary antibody for $30 \mathrm{~min}$, followed by DAB staining. After washing in PBS, the cell nucleus was re-dyed with hematoxylin. The sections were examined with an Olympus BX51 microscope (Olympus), and images were acquired with a camera (Olympus). The results were quantified by Image-Pro Plus 6.0 software.

\section{Transfection of Prx I small interfering RNAs}

Three different siRNA duplexes targeting three specific sequences of Prx I (NP_859048.1) and a scrambled siRNA as a negative control were designed and synthesized by GenePharma (Shanghai, China), according to siRNA design guidelines (45). p38 siRNA (sc-29433) was purchased from
Santa Cruz Biotechnology. For siRNA transfection, cells were seeded at $20 \%-40 \%$ confluence and transfected with siRNA (10 $\mathrm{n} M$ for Prx I, 20, or $50 \mathrm{n} M$ for p38) in SiRNA-Mate ${ }^{\mathrm{TM}}$ (GenePharma) the next day, according to the manufacturer's protocol. Prx I knockdown was evaluated by Western blot. The sense strand nucleotide sequence for Prx I No. 1 siRNA was $5^{\prime}$ GAUCAUUGCUUUCAGUGAUTT- $3^{\prime}$, and the anti-sense sequence was 5'-AUCACUGAAAGCAAUGAUCTT-3'; Prx I No. 2 siRNA was 5'-GCACCAUUGCUCAGGAUUATT-3', and the anti-sense sequence was $5^{\prime}$-UAAUCCUGAGCAAUG GUGCTT-3'; and Prx I No. 3 siRNA was 5'-CAGCCUGUCU GACUACAAATT-3', and the anti-sense sequence was $5^{\prime}$ UUUGUAGUCAGACAGGCUGTT-3'. The negative control siRNA (siNeg) sense sequence was 5'-UUCUCCGAACGU GUCACGUTT-3', whereas the anti-sense sequence was $5^{\prime}$ ACGUGACACGUUCGGAGAATT-3'.

\section{Generation of Prx I eukaryotic expression vector and transfection}

The cDNA encoding human entire Prx I (NP_859048.1) was obtained by reverse-transcription PCR and cloned into pIRES2-EGFP for generating Prx I eukaryotic expression vector. The forward primer was $5^{\prime}$-ATGTCTTCAGGAAAT GCT-3', and the reverse primer was 5'-TCACTTCTGCTT GGAGAA-3'. The acquired vector was verified by DNA sequence analysis and transfected into EC109 cells by lipofectamine $^{\circledR} 3000$ (Invitrogen, Carlsbad, CA), according to the manufacturer's instruction. The transfection efficiency was determined, according to the strength of the green fluorescence. The expression level of Prx I was detected by Western blot. The empty vector of pIRES2-EGFP was used as a negative control.

\section{Expression and purification of Prx I, Prx II, and Prx I mutants}

The in vitro expression and purification of Prx I (NP_859048.1) and Prx II (NP_005800.3) were performed as previously described (30). His-tagged Prx I and Prx II vectors in the pET28a were cultured in Escherichia coli BL21, containing $30 \mathrm{~g} / \mathrm{ml}$ kanamycin at $37^{\circ} \mathrm{C}$ to an absorbance of 0.7 at $600 \mathrm{~nm}$; then, they were induced and expressed with $0.25 \mathrm{mM}$ Isopropyl-D-1-thiogalactopyranoside (IPTG) for $6 \mathrm{~h}$ before being harvested by centrifugation. The cell pellets were suspended in lysis buffer $\left(50 \mathrm{mM} \mathrm{NaH}{ }_{2} \mathrm{PO}_{4}\right.$ and $0.3 \mathrm{M} \mathrm{NaCl}, \mathrm{pH}$ 8.0) and disrupted by sonication. After centrifugation, the supernatant was applied to an Ni-beads column (QIAGEN) and washed three times with washing buffer $\left(50 \mathrm{mMNaH} \mathrm{PO}_{4}\right.$ and $0.3 \mathrm{M} \mathrm{NaCl}, \mathrm{pH}$ 8.0). The interested proteins were eluted with elution buffer $\left(50 \mathrm{mM} \mathrm{NaH} \mathrm{PO}_{4}, 0.3 \mathrm{M} \mathrm{NaCl}\right.$, and $200 \mathrm{~m} M$ Imidazole, $\mathrm{pH}$ 8.0), and the molecular weight of these proteins was confirmed by Commassie Blue staining (Supplementary Fig. S3). The concentration of the recombinant protein was measured, using a Bicinchoninic Acid (BCA) Protein Assay kit (Solarbio). To obtain Prx I Phe50 to Ala50 (F50A) and Prx I Arg128 to Ala50 (R128A) mutants, plasmids with sitedirected mutations were constructed by using QuikChange ${ }^{\mathrm{TM}}$ site-directed mutagenesis kit (Stratagene, Palo Alto, CA). The specific primers used for the point mutations of human Prx I genes were listed in Supplementary Table S3. After confirming a $100 \%$ identities match by DNA sequencing, the E. coli strain BL21 was transformed with the constructs for the next step of protein purification. 


\section{Measurement of the recombinant protein activity}

The role of compounds in the recombinant Prx I or Prx II protein activity was determined as previously described (51, 64). Each of the protein samples with different concentrations of compound $(6.25,12.5,25,50$, and $100 \mu M / L)$ was incubated with $50 \mathrm{mM}$ Hepes- $\mathrm{HCl}(\mathrm{pH} 7.0)$, containing $1 \mathrm{~m} M$ DTT for $10 \mathrm{~min}$ at room temperature. The reaction was initiated by addition of $6 \mu 1 \mathrm{H}_{2} \mathrm{O}_{2}$ (final concentration $100 \mu M$ ) and incubated for $5 \mathrm{~min}$. The reaction was stopped by adding $7 \mu \mathrm{l} 5 \%$ (w/v) trichloroacetic acid (TCA). The residual $\mathrm{H}_{2} \mathrm{O}_{2}$ amount was measured, reflecting the inhibition activity of the corresponding compounds on the enzymes. The final reaction product was detected as follows: The reaction mixture was added with $4 \mu M / L$ Amplex Red and horseradish peroxidase (HRP). The remaining peroxide content was determined by measurement of an excitation wavelength of $530 \mathrm{~nm}$ and an emission wavelength of $590 \mathrm{~nm}$. For detecting the catalytic activity of Prx I, Prx I F50A, and Prx I R128A on $\mathrm{H}_{2} \mathrm{O}_{2}$, 25$200 \mu M$ of the proteins were added to the fixed reaction system as described earlier.

\section{Isothermal titration calorimetry}

The ITC experiments were carried out at $25^{\circ} \mathrm{C}$ with a Microcal ITC200 isothermal titration calorimeter (GE Healthcare), as previously reported (43). Sixty micromolar Prx I, Prx I F50A, or Prx I R128A solution in 15\% DMSO from purified stock solution in a buffer containing $50 \mathrm{~m} M$ HEPES (pH 7.0), $1 \mathrm{~m} M$ DTT were subjected to ITC experiment. The titrant was JDA-202 at a concentration of $2 \mathrm{~m} M$ in $15 \%$ DMSO. To correct the thermal effect due to mixing and dilution, a control experiment was performed by injecting the titrant (without JDA-202) into the protein solution. The $0.2 \mathrm{ml}$ sample cell was filled with $60 \mu M$ Prx I and stirred constantly at $750 \mathrm{rpm}$. The syringe was filled with $2 \mathrm{~m} M$ JDA-202 and titrated into the sample cell in one $0.4 \mu \mathrm{l}$ injection, followed by $2.0 \mu \mathrm{l}$ injections at $150 \mathrm{~s}$ intervals. After the background dilution heats were subtracted from the experimental data, the net titration data were analyzed with the Microcal ORIGIN V7.0 software (Microcal Software, Northampton, MA).

\section{Intracellular dihydroethidium assay}

Intracellular superoxide anion was measured by dihydroethidium (DHE), according to the manual operation. Briefly, harvested cells were washed twice by serum-free medium, loaded with $5 \mu M$ DHE. The cells were then incubated for $30 \mathrm{~min}$. Flow cytometry analysis or fluorescence microscope detection was carried out immediately. Ten thousand cells were collected and analyzed by a flow cytometer (Accuri C6, BD). The superoxide anion levels were calculated by the FlowJo software.

\section{Measurement of intracellular $\mathrm{H}_{2} \mathrm{O}_{2}$}

The $\mathrm{H}_{2} \mathrm{O}_{2}$ production from intact cells was measured, using the oxidation of the fluorogenic indicator Amplex Red in the presence of HRP, as previously reported (66). After treatment with 0,20 , and $40 \mu M$ JDA-202 for $12 \mathrm{~h}$, cells were harvested and counted. Next, $10^{5}$ cells/well in a $50 \mu \mathrm{l}$ reaction mixture ( $50 \mathrm{~m} M$ Tris-HCl, $\mathrm{pH}$ 7.0) were placed into a 96-well microplate. Then, $50 \mu \mathrm{l}$ Amplex Red reagent/HRP working solution was added to each well. The final concentrations of HRP and Amplex Red in the incubation were $5 \mathrm{U} / \mathrm{ml}$ and $50 \mu M$, respectively. The reaction was incubated at room temperature for $30 \mathrm{~min}$, and it was protected from light. The fluorescence density was recorded by a microplate reader (Biotek Synergy H1) with $530 \mathrm{~nm}$ excitation and $590 \mathrm{~nm}$ emission wavelengths.

\section{Xenograft studies}

All animal experiments were conducted in accordance with the guidelines of the Institutional Animal Care and Use Committee. Six-week-old male BALB/c nude mice, weighing $18-21 \mathrm{~g}$ at the beginning of the experiment, were purchased from Hunan Slack Scene of Laboratory Animal Co., Ltd. (Hunan, China) in this study. Mice were housed in a laminar flow under sterilized condition. EC109 cells were trypsinized and washed twice with PBS, and $0.2 \mathrm{ml}$ cells at the concentration of $5 \times 10^{7} / \mathrm{ml}$ were injected into the right pouch near the scapular region. Once the tumor volumes reached $100 \mathrm{~mm}^{3}$, mice were randomly divided into corresponding saline (vehicle) group, $\beta$-cyclodextrin (solvent) group, PTX $(10 \mathrm{mg} / \mathrm{kg})$ group, and JDA-202 $(20 \mathrm{mg} / \mathrm{kg})$ treatment group ( $n=7$ mice in each group). The treatment groups received JDA-202 intravenous injection daily for a period of 21 days. PTX was intravenously injected once every 3 days. Tumor volumes were measured at every 3 days. At the 21st day, the mice were euthanized and the tumors were isolated and weighed. Tumor size was determined by vernier caliper measurements. The body weight was measured at a 3 day interval to monitor drug toxicity.

\section{Statistical analysis}

Data were expressed as mean \pm standard deviation. Statistical differences in two groups were performed by student's $t$-test. One-way analysis of variance was used for a multiple-group comparison. $p$-values of 0.05 or less were considered statistically significant.

\section{Acknowledgments}

The authors would like to express their thanks to Dr. Chen Guoqiang from Shanghai Jiaotong University for the kind gift of the pET28a-Prx I and pET28a-Prx II expressing vectors, Dr. Sun Handong from Kunming Institute of Botany Chinese Academy of Sciences for the kind gift of Adenanthin, and Dr. Chen Zhesheng and Dr. Yang Donghua from St. John's University College of Pharmacy and Health Sciences and Dr. Chang Junbiao's group from Zhengzhou University for great suggestions in article writing. This work was supported by the National Natural Science Foundation of China (Project Nos. 81430085, 21372206, and 81172937 for H.-M.L.; Project Nos. 81270270 and 81470524 for W.Z. Project No. 21403200 for L.D.); PhD Educational Award from Ministry of Education (No. 20134101130001, for H.-M.L. and No. 20134101110013, for W.Z.); The 2013 Scientific Innovation Talent Award from Department of Education of Henan Province (No. 13HASTIT029, for W.Z.); The National key R \& D Program for "Key Projects" from Ministry of Science \& Technology (2016YFA0501800 for H.-M.L and W.Z.); and 2013 Outstanding Doctoral Dissertation Engagement Fund of Zhengzhou University (X.-J.S.). 


\section{Author Disclosure Statement}

No competing financial interests exist.

\section{References}

1. Aguilar-Melero P, Prieto-Alamo MJ, Jurado J, Holmgren A, and Pueyo C. Proteomics in HepG2 hepatocarcinoma cells with stably silenced expression of PRDX1. J Proteomics 79: 161-171, 2013.

2. Backos DS, Franklin CC, and Reigan P. The role of glutathione in brain tumor drug resistance. Biochem Pharmacol 83: 1005-1012, 2012.

3. Barton DL, Liu H, Dakhil SR, Linquist B, Sloan JA, Nichols CR, McGinn TW, Stella PJ, Seeger GR, Sood A, and Loprinzi CL. Wisconsin Ginseng (Panax quinquefolius) to improve cancer-related fatigue: A randomized, double-blind trial, N07C2. J Natl Cancer Inst 105: 1230-1238, 2013.

4. Block KI, Gyllenhaal C, Lowe L, et al. Designing a broadspectrum integrative approach for cancer prevention and treatment. Semin Cancer Biol 35 Suppl: S276-S304, 2015.

5. Brizuela M, Huang HM, Smith C, Burgio G, Foote SJ, and McMorran BJ. Treatment of erythrocytes with the 2-cys peroxiredoxin inhibitor, Conoidin A, prevents the growth of Plasmodium falciparum and enhances parasite sensitivity to chloroquine. PLoS One 9: e92411, 2014.

6. Cai CY, Zhai LL, Wu Y, and Tang ZG. Expression and clinical value of peroxiredoxin-1 in patients with pancreatic cancer. Eur J Surg Oncol 41: 228-235, 2015.

7. Cha MK, Suh KH, and Kim IH. Overexpression of peroxiredoxin I and thioredoxin1 in human breast carcinoma. $J$ Exp Clin Cancer Res 28: 93, 2009.

8. Chen MF, Keng PC, Shau H, Wu CT, Hu YC, Liao SK, and Chen WC. Inhibition of lung tumor growth and augmentation of radiosensitivity by decreasing peroxiredoxin I expression. Int J Radiat Oncol Biol Phys 64: 581-591, 2006.

9. Dudley DT, Pang L, Decker SJ, Bridges AJ, and Saltiel AR. A synthetic inhibitor of the mitogen-activated protein kinase cascade. Proc Natl Acad Sci U S A 92: 7686-7689, 1995.

10. Fan CY, Chou HC, Lo YW, Wen YF, Tsai YC, Huang H, and Chan HL. Proteomic and redox-proteomic study on the role of glutathione reductase in human lung cancer cells. Electrophoresis 34: 3305-3314, 2013.

11. Fujita Y, Nakanishi T, Hiramatsu M, Mabuchi H, Miyamoto Y, Miyamoto A, Shimizu A, and Tanigawa N. Proteomicsbased approach identifying autoantibody against peroxiredoxin VI as a novel serum marker in esophageal squamous cell carcinoma. Clin Cancer Res 12: 6415-6420, 2006.

12. Gao MC, Jia XD, Wu QF, Cheng Y, Chen FR, and Zhang J. Silencing Prx1 and/or Prx5 sensitizes human esophageal cancer cells to ionizing radiation and increases apoptosis via intracellular ROS accumulation. Acta Pharmacol Sin 32: 528 536, 2011.

13. Gong F, Hou G, Liu H, and Zhang M. Peroxiredoxin 1 promotes tumorigenesis through regulating the activity of $\mathrm{mTOR} / \mathrm{p} 70 \mathrm{~S} 6 \mathrm{~K}$ pathway in esophageal squamous cell carcinoma. Med Oncol 32: 455-464, 2015.

14. Guo QJ, Mills JN, Bandurraga SG, Nogueira LM, Mason NJ, Camp ER, Larue AC, Turner DP, and Findlay VJ. MicroRNA-510 promotes cell and tumor growth by targeting peroxiredoxin 1 in breast cancer. Breast Cancer Res 15: R70, 2013.

15. He T, Banach-Latapy A, Vernis L, Dardalhon M, Chanet R, and Huang ME. Peroxiredoxin 1 knockdown potentiates beta-lapachone cytotoxicity through modulation of reactive oxygen species and mitogen-activated protein kinase signals. Carcinogenesis 34: 760-769, 2013.

16. Hoshino I, Matsubara H, Akutsu Y, Nishimori T, Yoneyama Y, Murakami K, Sakata H, Matsushita K, and Ochiai T. Tumor suppressor Prdx1 is a prognostic factor in esophageal squamous cell carcinoma patients. Oncol Rep 18: 867-871, 2007.

17. Hoshino I, Matsubara H, Hanari N, Mori M, Nishimori T, Yoneyama Y, Akutsu Y, Sakata H, Matsushita K, Seki N, and Ochiai T. Histone deacetylase inhibitor FK228 activates tumor suppressor Prdx1 with apoptosis induction in esophageal cancer cells. Clin Cancer Res 11: 7945-7952, 2005.

18. Hou JK, Huang Y, He W, Yan ZW, Fan L, Liu MH, Xiao WL, Sun HD, and Chen GQ. Adenanthin targets peroxiredoxin I/II to kill hepatocellular carcinoma cells. Cell Death Dis 5: e1400, 2014.

19. Huang LJ, Chen SX, Huang Y, Luo WJ, Jiang HH, Hu QH, Zhang PF, and Yi H. Proteomics-based identification of secreted protein dihydrodiol dehydrogenase as a novel serum markers of non-small cell lung cancer. Lung Cancer 54: 8794, 2006.

20. Jemal A, Bray F, Center MM, Ferlay J, Ward E, and Forman D. Global cancer statistics. CA Cancer J Clin 61: 69-90, 2011.

21. Jiang $\mathrm{H}, \mathrm{Wu} \mathrm{L}$, Mishra M, Chawsheen HA, and Wei Q. Expression of peroxiredoxin 1 and 4 promotes human lung cancer malignancy. Am J Cancer Res 4: 445-460, 2014.

22. Jiang L, Xiao X, Ren J, Tang Y, Weng H, Yang Q, Wu M, and Tang W. Proteomic analysis of bladder cancer indicates PrX-I as a key molecule in BI-TK/GCV treatment system. PLoS One 9: e98764, 2014.

23. Ke Y, Liu Z, Liu H-M, and Zi X. Novel acetal and halogen oridonin analogues potently induce apoptosis in prostate cancer cell lines via induction of p53/p73 and PUMA expression. Cancer Res 74 (19 Suppl): 1254, 2014.

24. Kim JA, Lee J, Margolis RL, and Fotedar R. SP600125 suppresses Cdk1 and induces endoreplication directly from G2 phase, independent of JNK inhibition. Oncogene 29: 1702-1716, 2010.

25. Kim JH, Bogner PN, Baek SH, Ramnath N, Liang P, Kim HR, Andrews C, and Park YM. Up-regulation of peroxiredoxin 1 in lung cancer and its implication as a prognostic and therapeutic target. Clin Cancer Res 14: 2326-2333, 2008.

26. Kim SY, Kim TJ, and Lee K-Y. A novel function of peroxiredoxin 1 (Prx-1) in apoptosis signal-regulating kinase 1 (ASK1)-mediated signaling pathway. FEBS Lett 582: 19131918, 2008.

27. Kim YJ, Lee WS, Ip C, Chae HZ, Park EM, and Park YM. Prx1 suppresses radiation-induced c-Jun NH2-terminal kinase signaling in lung cancer cells through interaction with the glutathione S-transferase Pi/c-Jun NH2-terminal kinase complex. Cancer Res 66: 7136-7142, 2006.

28. L'Allemain G. Deciphering the MAP kinase pathway. Prog Growth Factor Res 5: 291-334, 1994.

29. Lehrbach DM, Nita ME, and Cecconello I. Molecular aspects of esophageal squamous cell carcinoma carcinogenesis. Arq Gastroenterol 40: 256-261, 2003.

30. Liu CX, Yin QQ, Zhou HC, Wu YL, Pu JX, Xia L, Liu W, Huang X, Jiang T, Wu MX, He LC, Zhao YX, Wang XL, Xiao WL, Chen HZ, Zhao Q, Zhou AW, Wang LS, Sun HD, and Chen GQ. Adenanthin targets peroxiredoxin I and II to induce differentiation of leukemic cells. Nat Chem Biol 8: 486-493, 2012.

31. Liu CX, Zhou HC, Yin QQ, Wu YL, and Chen GQ. Targeting peroxiredoxins against leukemia. Exp Cell Res 319: 170-176, 2013. 
32. Ma D, Warabi E, Yanagawa T, Kimura S, Harada H, Yamagata K, and Ishii T. Peroxiredoxin I plays a protective role against cisplatin cytotoxicity through mitogen activated kinase signals. Oral Oncol 45: 1037-1043, 2009.

33. Ma YC, Ke Y, Zi X, Zhao W, Shi XJ, and Liu HM. Jaridonin, a novel ent-kaurene diterpenoid from Isodon rubescens, inducing apoptosis via production of reactive oxygen species in esophageal cancer cells. Curr Cancer Drug Targets 13: 611-624, 2013.

34. Ma YC, Su N, Shi XJ, Zhao W, Ke Y, Zi X, Zhao NM, Qin YH, Zhao HW, and Liu HM. Jaridonin-induced G2/M phase arrest in human esophageal cancer cells is caused by reactive oxygen species-dependent Cdc2-tyr15 phosphorylation via ATM-Chk1/2-Cdc25C pathway. Toxicol Appl Pharmacol 282: 227-236, 2015.

35. Manda G, Isvoranu G, Comanescu MV, Manea A, Debelec Butuner B, and Korkmaz KS. The redox biology network in cancer pathophysiology and therapeutics. Redox Biol 5: 347-357, 2015.

36. Mordret G. MAP kinase kinase: a node connecting multiple pathways. Biol Cell 79: 193-207, 1993.

37. Nguyen JB, Pool CD, Wong CY, Treger RS, Williams DL, Cappello M, Lea WA, Simeonov A, Vermeire JJ, and Modis Y. Peroxiredoxin-1 from the human hookworm Ancylostoma ceylanicum forms a stable oxidized decamer and is covalently inhibited by conoidin A. Chem Biol 20: 9911001, 2013.

38. Panis C, Victorino VJ, Herrera AC, Freitas LF, De Rossi T, Campos FC, Simao AN, Barbosa DS, Pinge-Filho P, Cecchini R, and Cecchini AL. Differential oxidative status and immune characterization of the early and advanced stages of human breast cancer. Breast Cancer Res Treat 133: 881-888, 2012.

39. Park SY, Yu X, Ip C, Mohler JL, Bogner PN, and Park YM. Peroxiredoxin 1 interacts with androgen receptor and enhances its transactivation. Cancer Res 67: 9294-9303, 2007.

40. Parkin DM, Bray F, Ferlay J, and Pisani P. Global cancer statistics, 2002. CA Cancer J Clin 55: 74-108, 2005.

41. Qi Y, Chiu JF, Wang L, Kwong DL, and He QY. Comparative proteomic analysis of esophageal squamous cell carcinoma. Proteomics 5: 2960-2971, 2005.

42. Qi YJ, He QY, Ma YF, Du YW, Liu GC, Li YJ, Tsao GS, Ngai SM, and Chiu JF. Proteomic identification of malignant transformation-related proteins in esophageal squamous cell carcinoma. J Cell Biochem 104: 1625-1635, 2008.

43. Qiao Y, Zhou B, Zhang M, Liu W, Han Z, Song C, Yu W, Yang Q, Wang R, Wang S, Shi S, Zhao R, Chai J, and Chang J. A novel inhibitor of the obesity-related protein FTO. Biochemistry 55: 1516-1522, 2016.

44. Ren P, Ye H, Dai L, Liu M, Liu X, Chai Y, Shao Q, Li Y, Lei N, Peng B, Yao W, and Zhang J. Peroxiredoxin 1 is a tumor-associated antigen in esophageal squamous cell carcinoma. Oncol Rep 30: 2297-2303, 2013.

45. Reynolds A, Leake D, Boese Q, Scaringe S, Marshall WS, and Khvorova A. Rational siRNA design for RNA interference. Nat Biotechnol 22: 326-330, 2004.

46. Rhee SG, Woo HA, Kil IS, and Bae SH. Peroxiredoxin functions as a peroxidase and a regulator and sensor of local peroxides. J Biol Chem 287: 4403-4410, 2012.

47. Rho JH, Qin S, Wang JY, and Roehrl MH. Proteomic expression analysis of surgical human colorectal cancer tissues: up-regulation of PSB7, PRDX1, and SRP9 and hypoxic adaptation in cancer. J Proteome Res 7: 2959-2972, 2008.

48. Riddell JR, Bshara W, Moser MT, Spernyak JA, Foster BA, and Gollnick SO. Peroxiredoxin 1 controls prostate cancer growth through Toll-like receptor 4-dependent regulation of tumor vasculature. Cancer Res 71: 1637-1646, 2011.

49. Shimada Y, Imamura M, Wagata T, Yamaguchi N, and Tobe T. Characterization of 21 newly established esophageal cancer cell lines. Cancer 69: 277-284, 1992.

50. Sosa V, Moliné T, Somoza R, Paciucci R, Kondoh H, and Lleonart ME. Oxidative stress and cancer: An overview. Ageing Res Rev 12: 376-390, 2013.

51. Sun J, Liu X, and Li Q. Molecular cloning, expression and antioxidant activity of a peroxiredoxin 2 homologue from Lampetra japonica. Fish Shellfish Immunol 28: 795-801, 2010.

52. Sun QK, Zhu JY, Wang W, Lv Y, Zhou HC, Yu JH, Xu GL, Ma JL, Zhong W, and Jia WD. Diagnostic and prognostic significance of peroxiredoxin 1 expression in human hepatocellular carcinoma. Med Oncol 31: 786, 2014.

53. Taniuchi K, Furihata M, Hanazaki K, Iwasaki S, Tanaka K, Shimizu T, Saito M, and Saibara T. Peroxiredoxin 1 promotes pancreatic cancer cell invasion by modulating p38 MAPK activity. Pancreas 44: 331-340, 2015.

54. Trzeciecka A, Klossowski S, Bajor M, Zagozdzon R, Gaj P, Muchowicz A, Malinowska A, Czerwoniec A, Barankiewicz J, Domagala A, Chlebowska J, Prochorec-Sobieszek M, Winiarska M, Ostaszewski R, Gwizdalska I, Golab J, Nowis D, and Firczuk M. Dimeric peroxiredoxins are druggable targets in human Burkitt lymphoma. Oncotarget 7: 17171731, 2015.

55. Turner-Ivey B, Manevich Y, Schulte J, Kistner-Griffin E, Jezierska-Drutel A, Liu Y, and Neumann CA. Role for Prdx 1 as a specific sensor in redox-regulated senescence in breast cancer. Oncogene 32: 5302-5314, 2013.

56. Valdameri G, Trombetta-Lima M, Worfel PR, Pires AR, Martinez GR, Noleto GR, Cadena SM, Sogayar MC, Winnischofer SM, and Rocha ME. Involvement of catalase in the apoptotic mechanism induced by apigenin in HepG2 human hepatoma cells. Chem Biol Interact 193: 180-189, 2011.

57. Wang VE, Grandis JR, and Ko AH. New strategies in esophageal carcinoma: Translational insights from signaling pathways and immune checkpoints. Clin Cancer Res 22: 4283-4290, 2016.

58. Wondrak GT. Redox-directed cancer therapeutics: molecular mechanisms and opportunities. Antioxid Redox Signal 11: 3013-3069, 2009.

59. Wu J, Shen SL, Chen B, Nie J, and Peng BG. Numb promotes cell proliferation and correlates with poor prognosis in hepatocellular carcinoma. PLoS One 9: e95849, 2014.

60. Yanagawa T, Ishikawa T, Ishii T, Tabuchi K, Iwasa S, Bannai S, Omura K, Suzuki H, and Yoshida H. Peroxiredoxin I expression in human thyroid tumors. Cancer Lett 145: 127-132, 1999.

61. Yanagawa T, Iwasa S, Ishii T, Tabuchi K, Yusa H, Onizawa K, Omura K, Harada H, Suzuki H, and Yoshida H. Peroxiredoxin I expression in oral cancer: a potential new tumor marker. Cancer Lett 156: 27-35, 2000.

62. Yang Y, Karakhanova S, Werner J, and Bazhin AV. Reactive oxygen species in cancer biology and anticancer therapy. Curr Med Chem 20: 3677-3692, 2013. 
63. Yang YJ, Baek JY, Goo J, Shin Y, Park JK, Jang JY, Wang SB, Jeong W, Lee HJ, Um HD, Lee SK, Choi Y, Rhee SG, and Chang TS. Effective killing of cancer cells through ROS-mediated mechanisms by AMRI-59 targeting and peroxiredoxin I. Antioxid Redox Signal 24: 453469, 2015.

64. Zheng YC, Duan YC, Ma JL, Xu RM, Zi X, Lv WL, Wang MM, Ye XW, Zhu S, Mobley D, Zhu YY, Wang JW, Li JF, Wang ZR, Zhao W, and Liu HM. Triazole-dithiocarbamate based selective lysine specific demethylase 1 (LSD1) inactivators inhibit gastric cancer cell growth, invasion, and migration. J Med Chem 56: 8543-8560, 2013.

65. Zhu X, Ding M, Yu ML, Feng MX, Tan LJ, and Zhao FK. Identification of galectin-7 as a potential biomarker for esophageal squamous cell carcinoma by proteomic analysis. BMC Cancer 10: 290, 2010.

66. Zielonka J, Zielonka M, Sikora A, Adamus J, Joseph J, Hardy M, Ouari O, Dranka BP, and Kalyanaraman B. Global profiling of reactive oxygen and nitrogen species in biological systems: high-throughput real-time analyses. $J$ Biol Chem 287: 2984-2995, 2012.

Address correspondence to: Dr. Hong-Min Liu

Key Laboratory of Advanced Pharmaceutical Technology Ministry of Education of China Co-Innovation Center of Henan Province for New Drug $R$ \& D and Preclinical Safety School of Pharmaceutical Sciences Zhengzhou University

100 Kexue Avenue Zhengzhou

Henan 450001 P.R. China

E-mail: liuhm@zzu.edu.cn

Dr. Wen Zhao

Key Laboratory of Advanced Pharmaceutical Technology Ministry of Education of China Co-Innovation Center of Henan Province for New Drug $R \& D$ and Preclinical Safety School of Pharmaceutical Sciences Zhengzhou University 100 Kexue Avenue Zhengzhou

Henan 450001 P.R. China

E-mail: zhaowen100@139.com
Dr. $\mathrm{Yu} \mathrm{Ke}$

Key Laboratory of Advanced Pharmaceutical Technology Ministry of Education of China Co-Innovation Center of Henan Province for New Drug $R \& D$ and Preclinical Safety School of Pharmaceutical Sciences

Zhengzhou University

100 Кехие Avenue Zhengzhou

Henan 450001 P.R. China

E-mail: ky@zzu.edu.cn

Date of first submission to ARS Central, March 18, 2016; date of final revised submission, September 18, 2016; date of acceptance, September 19, 2016.

\begin{tabular}{|c|}
\hline $\begin{aligned} & \text { Abbreviations Used } \\
\Delta \Psi m & =\text { mitochondrial membrane potential } \\
\mathrm{CC} & =\text { column chromatography } \\
\mathrm{DHE} & =\text { dihydroethidium } \\
\mathrm{DMSO} & =\text { dimethyl sulfoxide } \\
\mathrm{EC} & =\text { esophageal cancer } \\
\mathrm{ERK} & =\text { extracellular signal-regulated kinase } \\
\mathrm{ESC} & =\text { esophageal squamous carcinoma } \\
\mathrm{EtOAc} & =\text { ethyl acetate } \\
\mathrm{GPx} & =\text { glutathione peroxidase } \\
\mathrm{H}_{2} \mathrm{O}_{2} & =\text { hydrogen peroxide } \\
\mathrm{HCC} & =\text { hepatocellular carcinoma } \\
\mathrm{HRP} & =\text { horseradish peroxidase } \\
\mathrm{IC} & =\text { half maximal inhibitory concentration } \\
\mathrm{ITC} & =\text { isothermal titration calorimetry } \\
\mathrm{JNK} & =\text { c-Jun N-terminal kinase } \\
\mathrm{MAPK} & =\text { mitogen-activated protein kinase } \\
\mathrm{mRNA} & =\text { messenger RNA } \\
\mathrm{MTT} & =3 \text {-[4, 5-dimethylthiazol-2-yl }]-2, \\
& 5 \text {-diphenyltetrazolium bromide } \\
\mathrm{NAC} & =\text { N-acetylcysteine } \\
\mathrm{PBS} & =\text { phosphate-buffered saline } \\
\mathrm{PCR} & =\text { polymerase chain reaction } \\
\text { Prx I } & =\text { peroxiredoxin I } \\
\mathrm{PTX} & =\text { paclitaxel } \\
\mathrm{ROS} & =\text { reactive oxygen species } \\
\text { siRNA } & =\text { small or short interfering RNA } \\
\mathrm{SOD} 1 & =\text { superoxide dismutase } 1 \\
\mathrm{Trx} & =\text { thioredoxin }\end{aligned}$ \\
\hline
\end{tabular}

